\title{
Secondary Metabolites from Endophytic Fungus Penicillium pinophilum Induce ROS-Mediated Apoptosis through Mitochondrial Pathway in Pancreatic Cancer Cells
}

Authors

Affiliations
Mytre Koul ${ }^{1,5}$, Samdarshi Meena ${ }^{2,5}$, Ashok Kumar $^{1,5}$, Parduman Raj Sharma ${ }^{1,5}$, Venugopal Singamaneni ${ }^{2,5}$, Syed Riyaz-Ul-Hassan ${ }^{3,5}$, Abid Hamid ${ }^{1,5}$, Asha Chaubey ${ }^{4,5}$, Anil Prabhakar ${ }^{2}$, Prasoon Gupta ${ }^{2,5}$, Shashank Singh ${ }^{1,5}$

The affiliations are listed at the end of the article

\author{
Key words \\ - Penicillium pinophilum \\ - Allium schoenoprasum \\ - Trichocomaceae \\ - cytotoxicity \\ - skyrin \\ - dicatenarin \\ - 2D-SEPBOX \\ - anthraquinone
}

received May 30, 2015

revised October 19, 2015

accepted October 20, 2015

Bibliography

DOI http://dx.doi.org/

10.1055/s-0035-1558308

Published online February 5,

2016

Planta Med 2016; 82: 344-355

(c) Georg Thieme Verlag KG

Stuttgart · New York .

ISSN 0032-0943

\section{Correspondence \\ Shashank Singh, \\ M. Pharm, Ph.D. \\ Cancer Pharmacology Division \\ CSIR - Indian Institute of \\ Integrative Medicine \\ Canal Road \\ Jammu 180001 \\ India \\ Phone: \\ +91191258500613352 \\ Fax: + 911912569019 \\ sksingh@iiim.ac.in}

Correspondence

Prasoon Gupta, Ph.D.

Natural Product

Chemistry Division

CSIR - Indian Institute of

Integrative Medicine

Canal Road

Jammu 180001

India

Phone:

+ 91191258500613218

Fax: + 911912569019

guptap@iiim.ac.in

\section{Abstract}

$\checkmark$

The endophytic fungus strain MRCJ-326, isolated from Allium schoenoprasum, which is also known as Snow Mountain Garlic or Kashmiri garlic, was identified as Penicillium pinophilum on the basis of morphological characteristics and internal transcribed spacer region nucleotide sequence analysis. The endophytic fungus extract was subjected to 2D-SEPBOX bioactivity-guided fractionation and purification. The anthraquinone class of the bioactive secondary metabolites were isolated and characterized as oxyskyrin (1), skyrin (2), dicatenarin (3), and 1,6,8-trihydroxy-3-hydroxy methylanthraquinone (4) by spectral analysis. Dicatenarin and skyrin showed marked growth inhibition against the NCI60/ATCC panel of human cancer cell lines with least $\mathrm{IC}_{50}$ values of $12 \mu \mathrm{g} /$ $\mathrm{mL}$ and $27 \mu \mathrm{g} / \mathrm{mL}$, respectively, against the human pancreatic cancer (MIA PaCa-2) cell line. The phenolic hydroxyl group in anthraquinones plays a crucial role in the oxidative process and bioactivity. Mechanistically, these compounds, i.e., dicatenarin and skyrin, significantly induce apoptosis and transmit the apoptotic signal via intracellular reactive oxygen species generation, thereby inducing a change in the mitochondrial transmembrane potential and induction of the mitochondrial-mediated apoptotic pathway. Our data indicated that dicatenarin and skyrin induce reactive oxygen species-mediated mitochondrial permeability transition and resulted in an increased induction of caspase-3 apoptotic proteins in human pancreatic cancer (MIA PaCa-2) cells. Dicatenarin showed a more pronounced cytotoxic/proapopotic effect than skyrin due to the presence of an additional phenolic hydroxyl group at C-4, which increases oxidative reactive oxygen species generation. This is the first report from $P$. pinophilum secreating these cytotoxic/proapoptotic secondary metabolites.

\author{
Abbreviations \\ $\nabla$ \\ ACN: acetonitrile \\ COSY: $\quad$ correlation spectroscopy \\ DAPI: 4',6-diamidino-2-phenylindole \\ DCFH-DA: $\quad 2^{\prime}, 7^{\prime}$ - dichlorofluorescein diacetate \\ DMSO: dimethyl sulfoxide \\ DNA-PK: DNA dependent protein kinase \\ EDTA: ethylene diaminetetracetic acid \\ ELISA: enzyme linked immunosorbent as- \\ say \\ ESIMS: electrospary ionization mass spec- \\ trometry \\ HMBC: heteronuclear multiple bond corre- \\ lation \\ HPLC: high-performance liquid chroma- \\ tography \\ HRMS: high-resolution mass spectrometry \\ ITS: internal transcribed spacer region \\ LC: liquid chromatography \\ LC-MS: liquid chromatography mass spec- \\ trometry \\ LC-MS/MS: liquid chromatography mass spec- \\ trometry/mass spectrometry \\ LC-QTOF: liquid chromatography quadrupole \\ time-of-flight \\ MTP: mitochondrial transmembrane \\ potential \\ mTOR: mammalian target of rapamycin \\ MW: molecular weight \\ PBS: $\quad$ phosphate buffered saline \\ PCR: $\quad$ polymerase chain reaction \\ PDA: potato dextrose agar \\ PI: $\quad$ propidium iodide \\ rDNA: ribosomal DNA \\ ROS: $\quad$ reactive oxygen species \\ UV: $\quad$ ultraviolet
}

1D NMR: one dimensional nuclear magnetic resonance

2D NMR: two dimensional nuclear magnetic resonance 
2D-SEPBOX: two dimensional SEPBOX

${ }^{1} \mathrm{H}-{ }^{1} \mathrm{H}$ COSY: correlation spectroscopy

${ }^{1} \mathrm{H}$ NMR: $\quad$ proton nuclear magnetic resonance

${ }^{13}$ C NMR: carbon nuclear magnetic resonance
Supporting information available online at http://www.thieme-connect.de/products

\section{Introduction}

\section{$\nabla$}

Natural products have been exploited world over in hope of finding new pharmaceuticals. Development of the pharmaceutical industry has stimulated the search for novel natural products from diverse environments and organisms. In this context, secondary metabolites of microbial origin deserve special consideration. Microorganisms are able to produce a variety of secondary metabolites including cytotoxic and antiproliferative compounds, which are valuable in cancer drug discovery. Particularly, natural products from endophytic fungi have been the mainstay as a source for novel anticancer agents over decades [1]. Among all fungal genera's, Penicillium, undoubtedly, is one of the most scientifically exploited and is widespread both in terms of environment and geography. Substantial work has been carried out worldwide with regard to endophytism in Penicillium aimed at the characterization of secondary metabolites and their biological potentials. This has enhanced our knowledge and created opportunities for its pharmaceutical exploitation, along the lines of a historical tradition of drugs derived from Penicillium strains which started with the discovery of mycophenolic acid [2] and continued with the wonder drugs penicillin [3] and compactin [4]. Endophytic Penicillia produces diverse secondary metabolites including, alkaloids, chromones, depsidones, diterpenes, ergochromes, esters, flavonoids, lactones, lignans, peptides and depsipeptides, polyketides, quinones, sesquiterpenes, steroids, and xanthones [5,6]. A large number of cytotoxic metabolites have been produced by Penicillium sp., e.g., emodin is an anthraquinone produced by Penicillium islandicum and known as a specific inhibitor of protein tyrosine kinase $\mathrm{p} 56$ and protein kinase $\mathrm{C}$ [7]. Penicillium oxalicum produces an eragosterol peroxide that shows selective cytotoxicity against human colon carcinoma (COLO 205) cells. There are many examples of cytotoxic compounds produced from Penicillium sp., e.g., brefeldin A, oxaline, neoxaline, vermistatin, and mycophenolic acid [8]. In the present study, an important medicinal plant, Allium schoenoprasum L. (Alliaceae) or snow mountain garlic, was investigated for the presence of endophytic fungi. In 1965, Chopra et al. mentioned snow mountain garlic or "Kashmiri Garlic" as A. schoenoprasum. It is an important herb which grows well in the snow-covered mountains of the Western Himalayas at an altitude of 6000 feet above sea level. It has a characteristic property that it can survive in extremely cold temperatures, up to $-10^{\circ} \mathrm{C}$, with very little oxygen. Snow mountain garlic has acquired a strong reputation since ancient times regarding its health benefits. Snow mountain garlic has shown health benefits in diseases like diabetes, atherosclerosis, hypertension, and cancer $[9,10]$. These protective effects appear to be related to the presence of organosulfur compounds, predominantly allyl derrivatives. Considering its medicinal properties, we selected it as a host plant for endophytic isolation, as host provides nutrients to endophytes and they help the host plant to resist biotic/abiotic stress by producing a number of bioactive compounds that can be exploited for pharmacological purposes. In this study, we isolated the endophytic fungus Penicillium pinophilum from snow mountain garlic bulbs and identified it by morphological and molecular characteristics, as de- scribed in this paper. In our initial study, the ethyl acetate extract of strain MRCJ-326 showed significant cytotoxic activity against the NCI60/ATCC panel of human cancer cell lines, with the lowest $\mathrm{IC}_{50}$ value of $3.5 \mu \mathrm{g} / \mathrm{mL}$ for human pancreatic cancer (MIA PaCa-2) cells. During the course of the metabolite profiling of the ethyl acetate extract (LC-MS) of strain MRCJ-326, we identified a series of mono- or dimeric anthraquinones, oxyskyrin (1), skyrin (2), dicatenarin (3), and 1,6,8-trihydroxy-3-hydroxymethylanthraquinone (4) [11-13]. The structures of these compounds were further confirmed by spectral analysis after isolation using the 2D-SEPBOX method. Purified and characterized compounds 1-4 were further studied for in vitro cytotoxic potential and apoptotic studies.

\section{Results \\ $\nabla$}

Isolated endophytic fungal strain MRCJ-326 from the bulb of $\mathrm{Al}$ lium sp. (snow mountain garlic) has shown morphological distinct characteristic features like hypha and spores of the genus Penicillium ( $\bullet$ Fig. 1). The corresponding ITS-rDNA sequence of the endophytic fungus ( $\bullet$ Fig. 2) in BlastN similarity analysis revealed $100 \%$ sequence similarity with Penicillium pinophilum. In our initial screening, the ethyl acetate extract of $P$. pinophilum exhibited concentration-dependent in vitro cytotoxicity against the NCI60/ATCC panel of human cancer cell lines with the lowest $\mathrm{IC}_{50}$ value of $3.5 \mu \mathrm{g} / \mathrm{mL}$ against human pancreatic cancer (MIA PaCa-2) cells ( Table 1). Further LC-MS/MS analysis of the ethyl acetate extract showed the presense of an anthraquinone class of compounds and identified a series of four compounds, oxyskyrin (1), skyrin (2), dicatenarin (3), and 1,6,8-trihydroxy-3-hydroxymethylanthraquinone (4) (Fig.1S, Supporting Information). These compounds were further purified for biological screening using the 2D-SEPBOX method. All of the four known compounds 1-4 ( Fig. 3) were isolated in a single run using SEPBOX and were characterized using detailed spectroscopic analysis.

Compound 1 was obtained as an orange red powder. It showed UV absorption maxima $\lambda_{\max }$ at 215, 256, 300, and $462 \mathrm{~nm}$, which indicated the anthraquinone-type moiety. ESIMS data of 1 showed a base peak at $m / z 554.9[\mathrm{M}+\mathrm{H}]^{+}$, which inferred that 1 has an MW of 554. The molecular formula was established as $\mathrm{C}_{30} \mathrm{H}_{17} \mathrm{O}_{11}$ based on the prominent signals detected at $\mathrm{m} / z 553.2$ $[\mathrm{M}-\mathrm{H}]^{-}$in the LC-HRMS spectra. The ${ }^{13} \mathrm{C}$ NMR data of 1 (Table $1 \mathrm{~S}$, Supporting Information) showed signals corresponding to 25 carbons. ${ }^{1} \mathrm{H}$ NMR showed proton signals of one aromatic methyl group resonating at $\delta_{\mathrm{H}} 2.48$ p.p.m., one oxymethylene at $\delta_{\mathrm{H}} 4.87$ p.p.m., one aromatic singlet at $\delta_{\mathrm{H}} 6.81$ p.p.m $(2 \mathrm{H})$, two aromatic broad singlets at $\delta_{\mathrm{H}} 7.26$ and 7.09 p.p.m., and two aromatic doublets at $\delta_{\mathrm{H}} 7.66$ and 7.51 p.p.m. The ${ }^{13} \mathrm{C}$ NMR data exhibited a total of 25 carbon peaks attributable to one methyl group at $\delta_{\mathrm{C}} 22.1\left(\mathrm{CH}_{3}-11^{\prime}\right)$, one oxymethylene at $\delta_{\mathrm{C}} 63.5\left(\mathrm{CH}_{2} \mathrm{OH}-11\right)$, five methine carbons, and eighteen quaternary carbon atoms. Detailed analysis of the ${ }^{13} \mathrm{C}$ spectrum disclosed signals for four carbonyl groups resonating at $\delta_{\mathrm{C}} 188.8$ (C-9), 189.1 (C-9'), 181.1 (C$10)$, and $180.0\left(\mathrm{C}-10^{\prime}\right)$, six oxygenated aromatic carbon atoms at $\delta_{\mathrm{C}} 164.3(\mathrm{C}-1), 163.0\left(\mathrm{C}-1^{\prime}\right), 167.4\left(\mathrm{C}-6 / 6^{\prime}\right)$, and $164.5\left(\mathrm{C}-8 / 8^{\prime}\right)$, and 


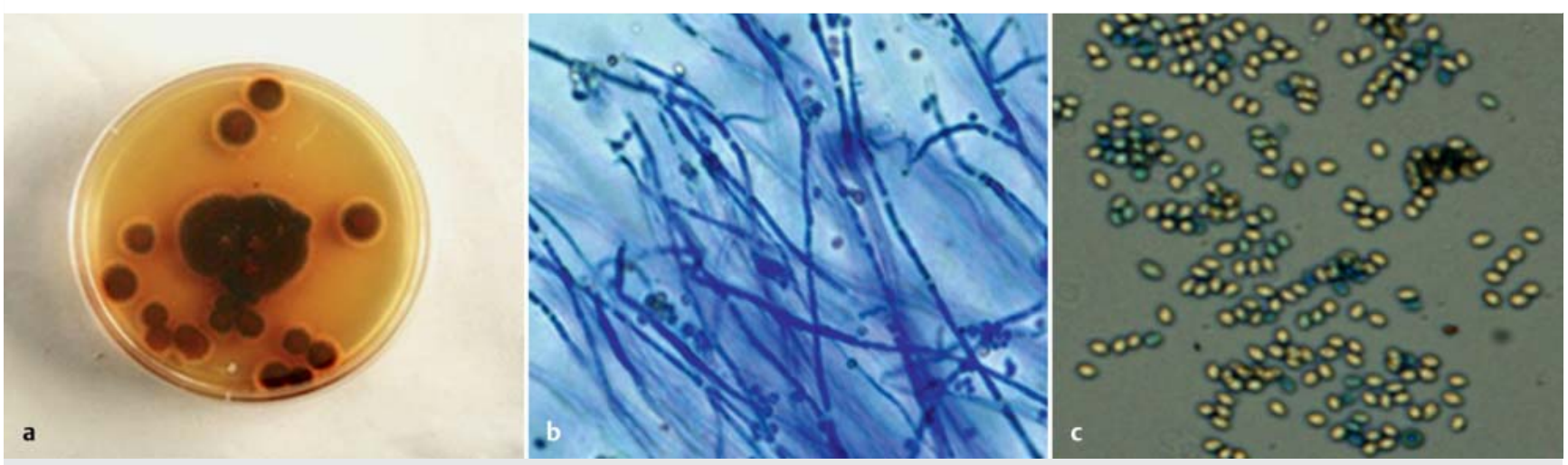

Fig. 1 Morphology of isolate MRCJ-326 (P. pinophilum). a Appearance of colonies on PDA; b, $\mathbf{c}$ Fungal isolate (hypha and spores) observed under a compound light microscope at 40×. (Color figure available online only.)

TTACCGAGTGCGGGCCCTCGCGGCCCAACCTCCCACCCTTGTCTCTATACACCTGTTG CTTTGGCGGGCCCACCGGGGCCACCTGGTCGCCGGGGGACGCACGTCTCCGGGCCCG CGCCCGCCGAAGCGCTCTGTGAACCCTGATGAAGATGGGCTGTCTGAGTACTGTGAA AAT'TGTCAAAACITTCAACAATGGATCTCTTGGTICCGGCATCGATGAAGAACGCAG CGAAATGCGATAAGTAATGTGAATTGCAGAATTCCGTGAATCATCGAATCTTTGAAC GCACATTGCGCCCCCTGGCATTCCGGGGGGCATGCCTGTCCGAGCGTCATTTCTGCC CTCAAGCACGGGTTGTGTGTTGGGTGTGGTCCCCCCGGGGACCTGCCCGAAAGGCAG CGGCGACGT

Fig. 2 Sequencing of endophytic fungus P. pinophilum.

eighteen aromatic carbons at $\delta_{\mathrm{C}} 120.8$ (C-2), $126.6\left(\mathrm{C}-2^{\prime}\right), 152.2$ (C3), $148.6\left(\mathrm{C}-3^{\prime}\right), 120.1$ (C-4), 122.0 (C-4'), 133.7 (C-4a), 132.3 (C-4a '), 124.2 (C-5/5'), 108.1 (C-7/7'), 107.2 (C-8a/8a'), 118.6 (C-9a), 115.1 (C-9a'), 133.3 (C-10a), and 132.2 (C-10a'). Further analysis of $1 \mathrm{D}$ together with 2D data revealed that we were dealing with a dimeric anthraquinone like emodin. Comparison of NMR data and UV spectra of 1 with those of emodin, as well as consideration of the MW, suggested that $\mathbf{1}$ is a non-symmetrical anthraquinone including one emodin and one 1,6,8-trihydroxy-3-hydroxymethylanthraquinone unit. The ${ }^{1} \mathrm{H}^{1}{ }^{1} \mathrm{H}$ COSY spectrum showed that the aromatic methyl signal $\delta_{\mathrm{H}} 2.48$ correlated to the metacoupled protons $\mathrm{H}-2^{\prime}$ and $\mathrm{H}-4^{\prime}$, and an oxymethylene signal at $\delta_{\mathrm{H}} 4.87$ correlated to $\mathrm{H}-2$ and $\mathrm{H}-4$. A methyl signal at $\delta_{\mathrm{H}} 2.48$ and an oxymethylene signal at $\delta_{\mathrm{H}} 4.87$ also showed a strong $\mathrm{HMBC}$ correlation with $\mathrm{C}^{2} 2^{\prime} / 4^{\prime}$ and $\mathrm{C}-2 / 4$, respectively. Furthermore, the linkage between these two units was confirmed at $\mathrm{C}-5 / 5^{\prime}$ by the HMBC correlations of $\mathrm{H}-7$ to $\mathrm{C}-5$ and $\mathrm{H}-7$ ' to $\mathrm{C}-5$ ' (Fig. 4 S, Supporting Information). From the above data, it can be concluded that the structure of oxyskyrin was previously reported from $P$. islandicum $[11,12]$.

Compound 2 was obtained as a light orange red powder with UV absorption maxima identical to those of oxyskyrin (1), likewise isolated during this study. LC-HRMS exhibited a prominent peak at $m / z 537.2[\mathrm{M}-\mathrm{H}]^{-}$with a 16 mass unit decrease compared with the MW of $\mathbf{1}$, which established the molecular formula $\mathrm{C}_{30} \mathrm{H}_{17} \mathrm{O}_{10}$ for 2. Comparison of the ${ }^{1} \mathrm{H}$ NMR spectra of $\mathbf{2}$ and $\mathbf{1}$ showed a close relationship between both compounds, except for the presence of an additional methyl group and the absence of a $\mathrm{CH}_{2}-\mathrm{OH}$ group in 2 . The ${ }^{13} \mathrm{C}$ NMR data of $\mathbf{2}$ (Table $\mathbf{1} \mathrm{S}$, Supporting Information) showed signals corresponding to 15 carbons only, indicating that $\mathbf{2}$ is a symmetrical dimer consisting of two identical monomers. ${ }^{1} \mathrm{H}$ NMR showed proton signals of one aromatic methyl group resonating at $\delta_{\mathrm{H}} 2.35$ p.p.m., one aromatic singlet at $\delta_{\mathrm{H}} 6.63$ p.p.m., and two aromatic broad singlets resonating at $\delta_{\mathrm{H}} 7.21$ and 7.50 p.p.m. The ${ }^{13} \mathrm{C}$ NMR data exhibited 15 carbon peaks attributable to one methyl group, three methine carbons, and eleven quaternary carbon atoms. Further analysis of the ${ }^{13} \mathrm{C}$ spectrum disclosed signals for two carbonyl groups resonating at $\delta_{\mathrm{C}} 190.1\left(\mathrm{C}-9 / 9^{\prime}\right)$ and $186.1\left(\mathrm{C}-10 / 10^{\prime}\right)$, three oxygenated aromatic carbon atoms at $\delta_{\mathrm{C}} 162.0\left(\mathrm{C}-1 / 1^{\prime}\right), 164.7\left(\mathrm{C}-6 / 6^{\prime}\right)$, and $164.1\left(\mathrm{C}-8 / 8^{\prime}\right)$, and nine aromatic carbons at $\delta_{\mathrm{C}} 121.4\left(\mathrm{C}-2 / 2^{\prime}\right)$, 149.1 (C-3/3'), 123.1 (C-4/4'), 134.2 (C-4a/4a'), 125.1 (C-5/5'), $107.3\left(\mathrm{C}-7 / 7^{\prime}\right), 109.1\left(\mathrm{C}-8 \mathrm{a} / 8 \mathrm{a}^{\prime}\right), 113.1\left(\mathrm{C}-9 \mathrm{a} / 9 \mathrm{a}^{\prime}\right)$ and $\delta_{\mathrm{C}} 131.5(\mathrm{C}-$ $\left.10 \mathrm{a} / 10 \mathrm{a}^{\prime}\right)$, and one methyl at $21.7\left(\mathrm{C}-11 / 11^{\prime}\right)$. Comparison of the NMR data and UV spectra of $\mathbf{2}$, as well as consideration of the MW, suggested that $\mathbf{2}$ is a symmetrical dimer of two emodin units. The linkage between the emodin building blocks was confirmed by 2D NMR analysis, including ${ }^{1} \mathrm{H}^{1}{ }^{1} \mathrm{H}$ COSY and HMBC correlations. The ${ }^{1} \mathrm{H}-{ }^{1} \mathrm{H}$ spectrum showed that the aromatic methyl signal correlated to the meta-coupled protons $\mathrm{H}-2$ and $\mathrm{H}-4$. Furthermore, in the HMBC spectrum, the aromatic proton at $\delta_{\mathrm{H}} 6.63\left(\mathrm{H}-7 / 7^{\prime}\right)$ showed a strong correlation to a carbon resonated at $\delta_{\mathrm{C}} 125.1$, which was attributed to C-5/5' (Fig. 3 S, Supporting Information). The above data was fully comparable to the data of skyrin reported in the literature, and confirms the structure of 2 as skyrin [11,12].

Compound 3 was obtained as an orange powder and had an identical pattern in UV absorption maxima to those of 1 and 2, isolated along with this compound. LC-HRMS exhibited a prominent peak at $m / z 569.3[\mathrm{M}-\mathrm{H}]^{-}$with a 34 mass unit compared with the MW of 2, which established the molecular formula $\mathrm{C}_{30} \mathrm{H}_{17} \mathrm{O}_{12}$ for 3. Comparison of the ${ }^{1} \mathrm{H}$ NMR spectra of $\mathbf{3}$ and $\mathbf{2}$ showed a close relationship, except for the absence of one aromatic signal. Further analysis of the 1D and 2D NMR data of $\mathbf{3}$ and $\mathbf{2}$ confirmed that both share a similar skeleton and substituents, except for the additional presence of a free hydroxyl group at C-4 in 3. In analogy to 2, two isolated aromatic protons were detected in the ${ }^{1} \mathrm{H}-{ }^{1} \mathrm{H}$ COSY spectrum of 3 . In addition, the HMBC spectrum confirmed the ${ }^{13} \mathrm{C}$ assignments of all of the systems in the molecules (Table $1 \mathrm{~S}$, Supporting Information). In contrast to 2, the signal of a methyl group $\left(\delta_{\mathrm{H}} 2.21, \mathrm{CH}_{3}-11\right)$ in 3 exhibited a strong $J^{3} \mathrm{HMBC}$ correlation to a carbon resonating at $\delta_{\mathrm{C}} 159.9$ p.p.m., which was attributed to $\mathrm{C}-4$. Hence, an additional free hydroxyl group was connected to C-4. Thus, a planar structure of $\mathbf{3}$ was accomplished and confirmed as dicatenarin. The data was fully analogous to the data of dicatenarin reported in the literature [11]. 
Table 1 IC 50 values of the extract and isolated compounds against the NC160/ATCC panel of human cancer cell lines of different tissue origin. Data are expressed as the mean \pm SD.

\begin{tabular}{|c|c|c|c|c|c|c|}
\hline \multirow[b]{2}{*}{ S. No } & \multicolumn{6}{|l|}{$I C_{50}(\mu \mathrm{g} / \mathrm{mL})$} \\
\hline & $\begin{array}{l}\text { A549 } \\
\text { (lung cancer) }\end{array}$ & $\begin{array}{l}\text { MIA-PaCa-2 } \\
\text { (pancreatic cancer) }\end{array}$ & $\begin{array}{l}\text { HCT-116 } \\
\text { (colon cancer) }\end{array}$ & $\begin{array}{l}\text { T47D } \\
\text { (breast cancer) }\end{array}$ & $\begin{array}{l}\text { PC-3 } \\
\text { (prostate cancer) }\end{array}$ & $\begin{array}{l}\text { OVCAR-3 } \\
\text { (ovarian cancer) }\end{array}$ \\
\hline Extract & $7 \pm 0.60$ & $3.5 \pm 0.73$ & $4 \pm 1.00$ & $4.5 \pm 7.4$ & $9 \pm 0.73$ & $12.5 \pm 1.59$ \\
\hline Oxyskyrin & $>50$ & $>50$ & $48 \pm 6.28$ & $>50$ & - & - \\
\hline Skyrin & $38 \pm 3.89$ & $27 \pm 1.41$ & $32 \pm 1.77$ & $>50$ & $47 \pm 3.89$ & - \\
\hline Dicatenarin & $23 \pm 2.94$ & $12 \pm 1.77$ & $17 \pm 2.16$ & $29 \pm 4.02$ & $35 \pm 3.55$ & $26 \pm 4.63$ \\
\hline $\begin{array}{l}\text { 1,6,8-trihydroxy- } \\
\text { 3-hydroxymethy- } \\
\text { lantraquinone }\end{array}$ & $>50$ & $>50$ & $>50$ & $>50$ & - & - \\
\hline Gemcitabine & - & $0.95 \pm 0.01$ & - & - & - & - \\
\hline Paclitaxel & $6 \pm 0.20$ & - & $8.5 \pm 0.02$ & - & - & $2.6 \pm 0.20$ \\
\hline Doxorubicin & - & - & - & $0.053 \pm 0.01$ & - & - \\
\hline Mitomycin & - & - & - & - & $0.17 \pm 0.01$ & - \\
\hline
\end{tabular}

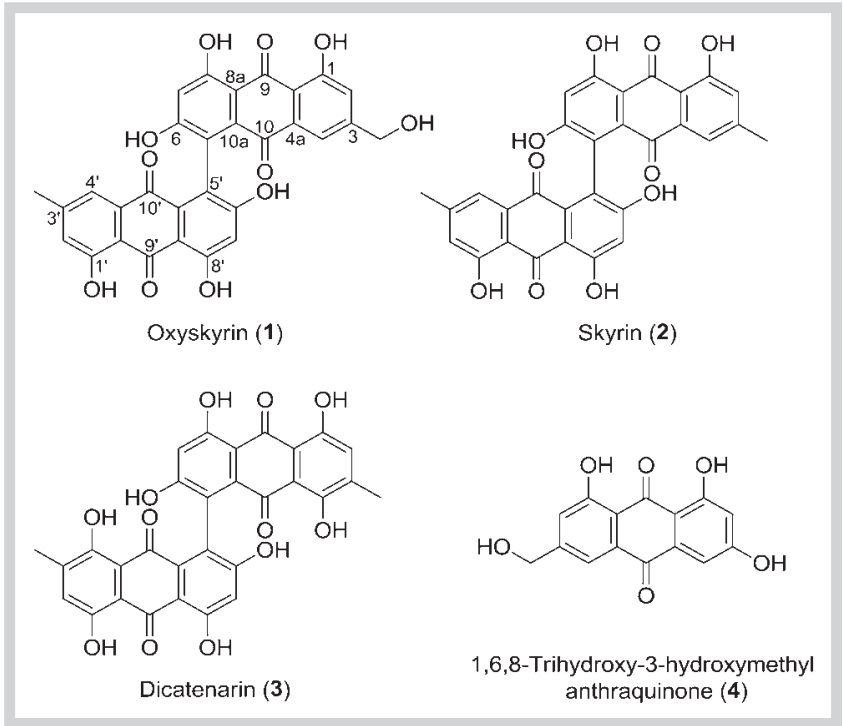

Fig. 3 Structures of isolated pure compounds (1-4).

Compound 4 was obtained as a yellow-orange needle with an m. p. between $285-290^{\circ} \mathrm{C}$ and UV absorption maxima quite similar to those of 1-3. LC-HRMS exhibited a prominent peak at $\mathrm{m} / \mathrm{z}$ $285.3[\mathrm{M}-\mathrm{H}]^{-}$corresponding to the molecular formula $\mathrm{C}_{15} \mathrm{H}_{9} \mathrm{O}_{6}$. The ${ }^{13} \mathrm{C}$ NMR (Table $1 \mathrm{~S}$, Supporting Information) spectrum of 4 showed a close relationship with 1 . Further analysis of the 1D and 2D NMR data of $\mathbf{4}$ confirmed that it has the same skeleton and substituents as $\mathbf{1}$; however, it is a monomer, as revealed from the molecular formula. A careful literature search revealed that 4 is a well-known 1,6,8-trihydroxy-3-hydroxymethylanthraquinone previously isolated from Penicillium janthinellum [13].

Of the four isolated compounds from the ethyl acetate extract, two, dicatenarin and skyrin, showed significant cytotoxicity with least $\mathrm{IC}_{50}$ values of 12 and $27 \mu \mathrm{g} / \mathrm{mL}$, respectively, against human pancreatic cancer (MIA PaCa-2) cells. However, in oxyskyrin and 1,6,8-trihydroxy-3-hydroxymethylanthraquinone, a significant cytotoxic effect was not observed ( Table 1).

Induction of apoptosis in MIA PaCa-2 cells was investigated by microscopic analysis of the DAPI-stained cells ( Fig.4). After $48 \mathrm{~h}$ of treatment, dicatenarin- and skyrin-treated MIA PaCa-2 cells demonstrated significant chromatin condensation and frag-

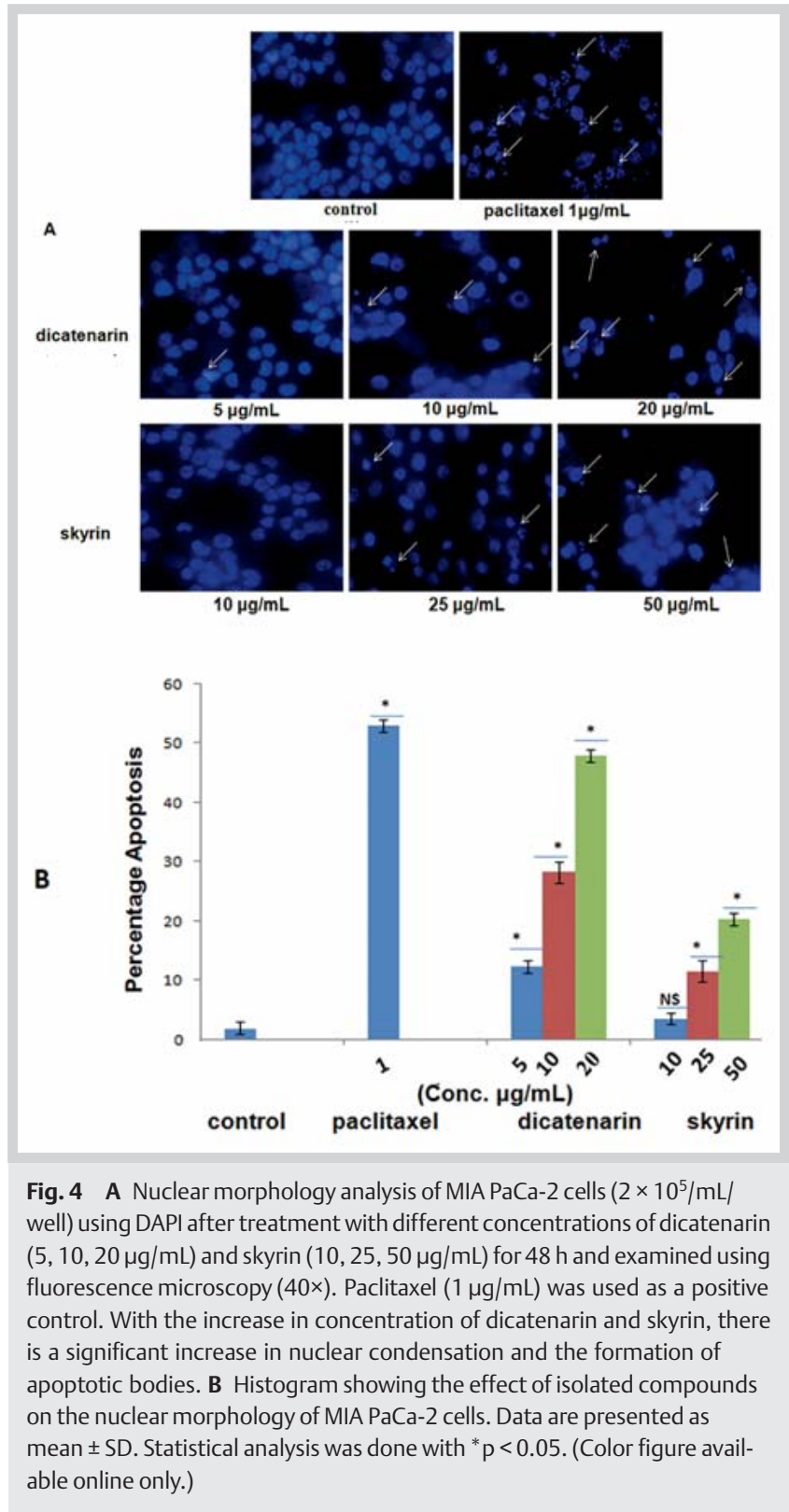



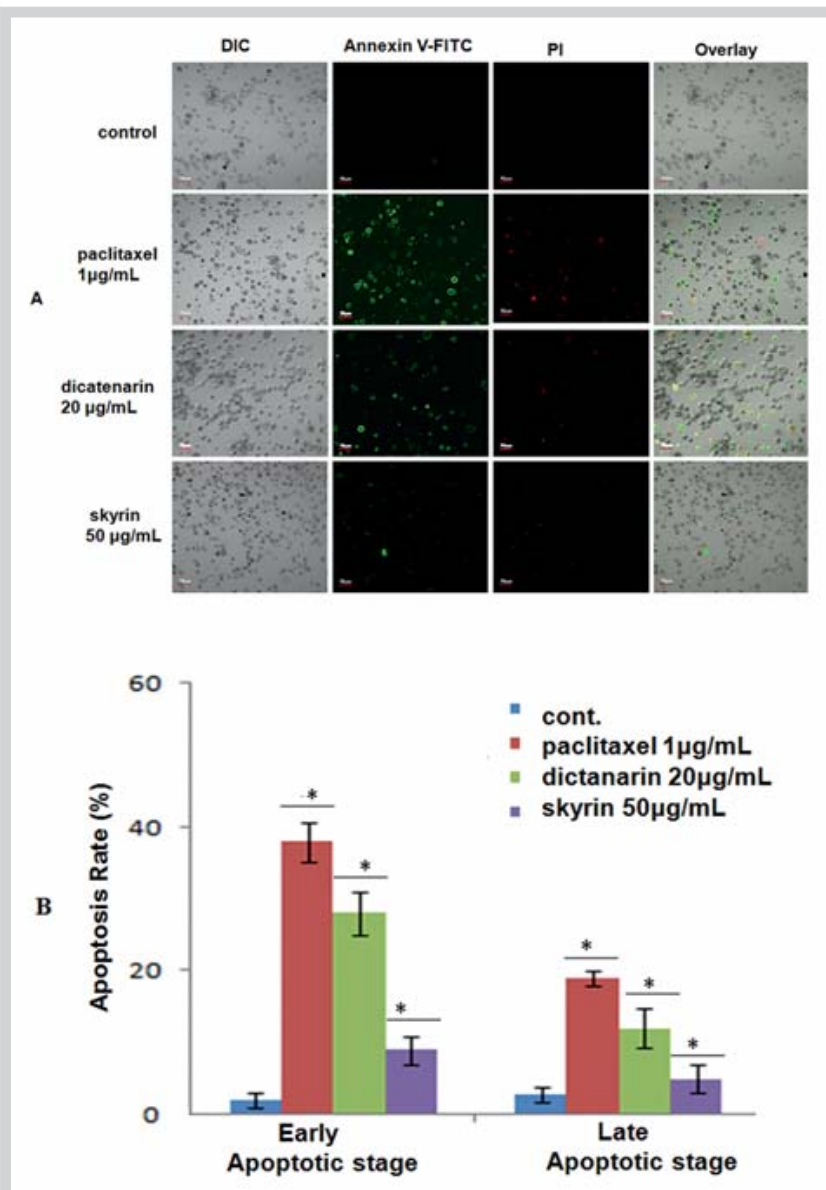

Fig. 5 The effects of compounds on the exposure of phosphatidylserine in MIA PaCa- 2 cells after $48 \mathrm{~h}$ treatment. Phosphatidylserine exposure was assessed by the annexin- $\mathrm{V} / \mathrm{Pl}$ assay, as described in methodology, and analyzed by confocal microscopy. The representative images $(\mathbf{A})$ and the percentage of cells in early and late stages of apoptosis were obtained by analysis of the cell images (mean \pm SD, three experiments), ${ }^{*} p<0.05$ (B). (Color figure available online only.)

mentation within the nucleus in a concentration-dependent manner. However, chromatin condensation and fragmentation was more prominent in dicatenarin- compared to skyrin-treated cells. In paclitaxel-treated MIA PaCa-2 cells, significant chromatin condensation was observed, and no chromatin condensation was observed in untreated controls.

To determine the extent of apoptosis of dicatenarin- and skyrininduced cell death in MIA PaCa-2 cells, the annexin V-FITC and PI dual staining was determined by laser scanning confocal microscopy. The data showed that untreated cells were negative for annexin V-FITC and PI staining, whereas positive cells were seen following both dicatenarin and skyrin treatment. The data also revealed that a significant amount of annexin $\mathrm{v}$ positive cells were seen in the case of dicatenarin, more than in skyrin, in the treated cells ( $\odot$ Fig. 5 ).

We determined ROS generation is induced by dicatenarin and skyrin in MIA PaCa-2 cells. Both dicatenarin and skyrin increased ROS generation in a concentration-dependent manner after $48 \mathrm{~h}$ treatment, but the phenomenon of ROS generation was much higher in dicatenarin-treated cells compared to skyrin. In $\mathrm{H}_{2} \mathrm{O}_{2}$ treated $(0.05 \%)$ MIA PaCa- 2 cells, prominent ROS generation was observed, whereas in the untreated control, no ROS generation was observed ( Fig. 6).

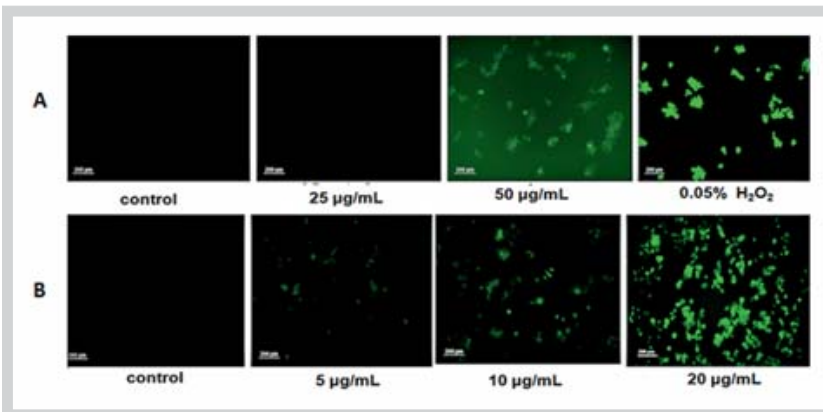

Fig. 6 The intracellular ROS level was detected by fluorescence microscopy using DCFH-DA after $48 \mathrm{~h}$ treatment. MIA PaCa-2 cells were treated with different concentrations of $(A)$ skyrin $(25,50 \mu \mathrm{g} / \mathrm{mL})$, (B) dicatenarin $(5,10$, $20 \mu \mathrm{g} / \mathrm{mL}$ ), and $0.05 \% \mathrm{H}_{2} \mathrm{O}_{2}$ and incubated with $5 \mu \mathrm{M} \mathrm{DCFH-DA}$ and examined by a fluorescence microscope $(10 \times)$. (Color figure available online only.)

Loss of MTP $(\Delta \psi \mathrm{m})$ in MIA PaCa-2 cells was measured with a laser scanning confocal microscope. MTP loss has been seen considerably in MIA PaCa-2 cells when exposed to different concentrations of dicatenarin and skyrin after $48 \mathrm{~h}$ treatment as compared to untreated cells. Moreover, dicatenarin treatment induced significant MTP loss compared to skyrin. In paclitaxel-treated $(1 \mu \mathrm{g} / \mathrm{mL})$ MIA PaCa-2 cells, prominent MTP loss was observed ( Fig. 7).

We further carried out immunofluorescence microscopic studies to determine the cytochrome $\mathrm{c}$ release from the mitochondria into the cytosol in MIA PaCa-2 cells during apoptosis. The distribution of cytochrome c was visualized by immunostaining the cells with anti-cytochrome c antibody. The localization of the mitochondria was revealed by staining the cells with MitoTracker Red. As we compared the distribution pattern of the endogenous cytochrome $\mathrm{c}$ and the morphological pattern of mitochondria, we found a prominent release of cytochrome $\mathrm{c}$ from the mitochondria in dicatenarin-treated MIA PaCa-2 cells, whereas skyrin-treated MIA PaCa- 2 cells showed a mild cytochrome c release at higher concentrations after $48 \mathrm{~h}$ treatment. In doxorubicin $(0.5 \mu \mathrm{g} / \mathrm{mL})$, the release of cytochrome c was very prominent ( $\odot$ Fig. 8).

We confirmed the participation of activated caspase- 3 in the events of apoptosis in MIA PaCa-2 cells induced by dicatenarin and skyrin after $48 \mathrm{~h}$ treatment. Caspase-3 activity was shown to be significantly elevated in dicatenarin-treated MIA PaCa-2 cells in a concentration-dependent manner ( Fig. 9). However, in comparison to dicatenarin, there was the least increament in caspase- 3 activity in skyrin-treated MIA PaCa- 2 cells, even at a higher concentration. In staurosporine-treated $(0.5 \mu \mathrm{g} / \mathrm{mL})$ MIA PaCa-2 cells, significant caspase- 3 activity was observed.

The clonogenic assay revealed that both dicatenarin and skyrin treatment significantly induced a reduction in the colony formation ability of MIA PaCa-2 cells. However, the reduction was less observed in skyrin-treated cells compared to dicatenarin treatment. In untreated MIA PaCa-2 cells, overlapping colonies were observed, whereas no overlapping cells were observed following treatment of both of the compounds ( $\odot$ Fig. 10).

\section{Discussion}

$\nabla$

Endophytic fungi have been a promising source for bioactive compounds, especially their anticancer potential. As great demand arises for new drug leads for cancer, there arises a need to exploit the endophytic fungi associated with medicinal plants. In 


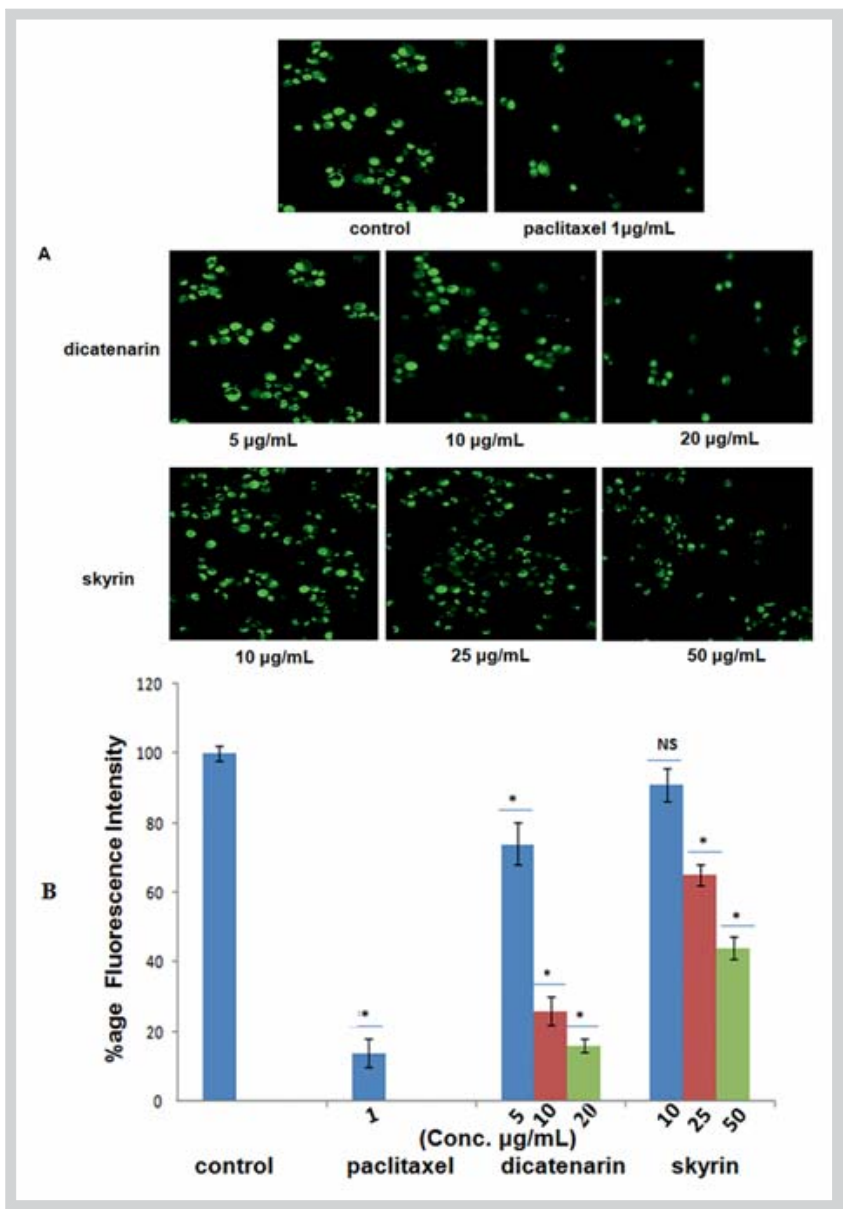

Fig. 7 A Loss of MTP $(\Delta \psi \mathrm{m})$ was measured in MIA PaCa-2 cells $\left(2 \times 10^{5} /\right.$ $\mathrm{mL} /$ well) treated with different concentrations of dicatenarin $(5,10,20 \mathrm{\mu g} /$ $\mathrm{mL})$ and skyrin $(10,25,50 \mu \mathrm{g} / \mathrm{mL})$ in 6-well plates for $48 \mathrm{~h}$ and incubated with rodamine $123(1.0 \mu \mathrm{M})$ in serum-free media for $20 \mathrm{~min}$ at $37^{\circ} \mathrm{C}$ and washed with PBS. The loss of MTP in MIA PaCa-2 cells was observed under a laser scanning confocal microscope using a $10 \times$ lens (Olympus Fluoview FV1000). B Histogram showing the effect of the isolated compounds on $\Delta \psi \mathrm{m}$ measured with a laser scanning confocal microscope by staining with rhodamine 123 . Fluorescence intensity indicates transmembrane potential of the mitochondria in the cells. Fluorescence intensity decreased in a concentration-dependent manner. Data are presented as mean \pm SD and statistical analysis was done with ${ }^{*} \mathrm{p}<0.05$. (Color figure available online only.)

the present study, we collected $A$. schoenoprasum bulbs from snow mountain regions of the Western Himalayas for the isolation of endophytic fungi. In 1965, Chopra et al. reported an enhancement of seven times in the medicinal properties of the garlic species growing at higher elevations due to a high content of organosulphur compounds [14]. It is also known to have abundant biological activities including immunomodulatory and anticancer properties [15]. The endosymbiotic nature of many endophytic fungi is to inherit their bioactive secondary metaboliteproducing capability from their host. Considering this a major reason, we selected it as a host plant $[4,16]$ and isolated the endophytic fungus $P$. pinophilum (MRCJ-326) growing from its bulbs. Endophytic fungal research is focussed on Penicillium sp. for its secondary metabolites displaying various pharmacological effects including anticancer activity [17]. Previously, it has been reported that a multitude of anticancer agents have been produced from Penicillium sp., e.g., brefeldin A, wortmanin, and chloctans-

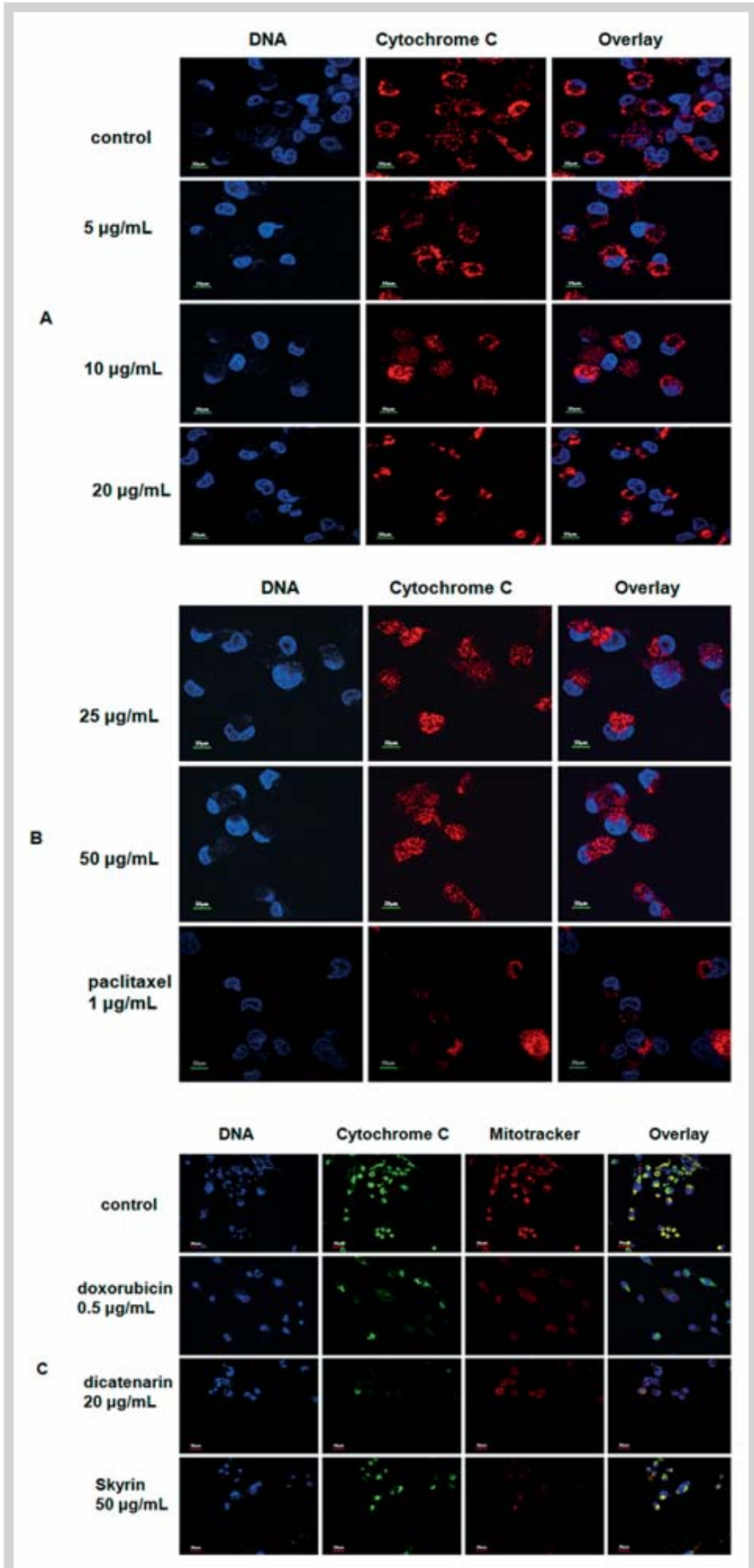

Fig. 8 MIA PaCa-2 cells were immunostained for cytochrome $\mathrm{c}$ release (red). MIA PaCa- 2 cells were treated with different concentrations of dicatenarin and skyrin for $48 \mathrm{~h}$ and stained with anti-cytochrome c antibody and Alexa Fluor 555-labeled secondary antibody. A Dicatenarin $(5,10$, $20 \mu \mathrm{g} / \mathrm{mL}$ ) induced the prominent release of cytochrome c from the mitochondria in a concentration-dependent manner. B Skyrin $(25,50 \mu \mathrm{g} / \mathrm{mL})$ induced the mild release of cytochrome $\mathrm{c}$ from the mitochondria at a higher concentration and paclitaxel $(1 \mu \mathrm{g} / \mathrm{mL})$ induced cytochrome $\mathrm{c}$ release. C Colocalization of cytochrome $\mathrm{c}$ and mitochondria was determined by confocal microscopy. Human pancreatic cancer (MIA PaCa-2) cells were immunostained for cytochrome $\mathrm{c}$ release ( $g r e e n$ ) and the mitochondria of the cells were stained with MitoTracker (red). MIA PaCa-2 cells were treated with dicatenarin $(20 \mu \mathrm{g} / \mathrm{mL})$, skyrin $(50 \mu \mathrm{g} / \mathrm{mL})$, and doxorubicin $(0.5 \mu \mathrm{g} /$ $\mathrm{mL}$ ) for $48 \mathrm{~h}$ and stained with anti-cytochrome $\mathrm{c}$ antibody and Alexa Fluor 488-labeled secondary antibody. Dicatenarin and doxorubicin induced the prominent release of cytochrome $\mathrm{c}$ from the mitochondria, whereas skyrin induced the mild release of cytochrome $\mathrm{c}$ from the mitochondria at a higher concentration. (Color figure available online only.) 


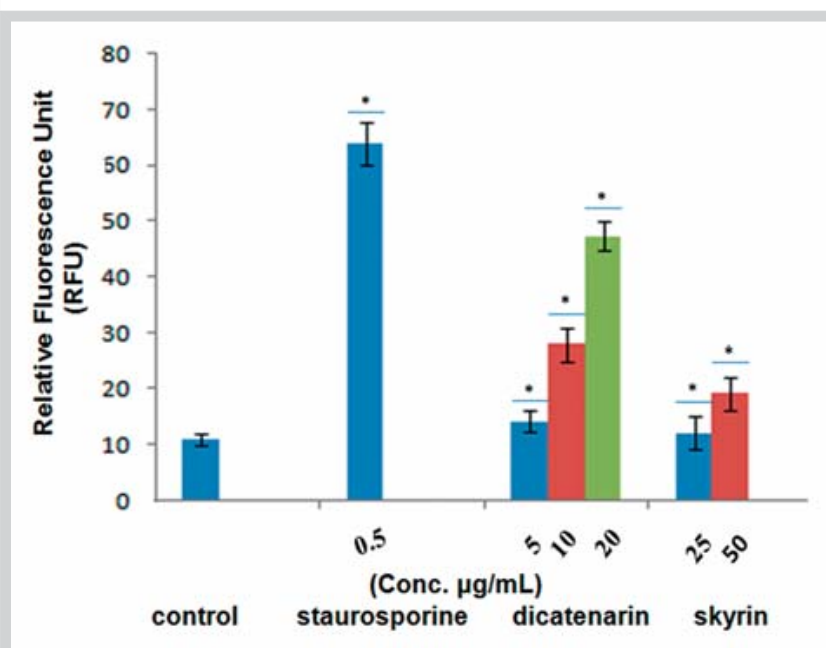

Fig. 9 Measurement of caspase-3 activity in MIA PaCa-2 cells. After treatment with different concentrations of dicatenarin $(5,10,20 \mu \mathrm{g} / \mathrm{mL})$ and skyrin $(25,50 \mu \mathrm{g} / \mathrm{mL})$ for $48 \mathrm{~h}$, relative fluorescence units were determined. Staurosporine $(0.5 \mu \mathrm{g} / \mathrm{mL})$ was used as a positive control. Data are presented as mean \pm SD and statistical analysis was done with ${ }^{*} p<0.05$. (Color figure available online only.)

pirone A [8]. In the present study, the crude ethyl acetate extract of the endophytic fungus $P$. pinophilum has been evaluated for in vitro cytotoxicity (\% growth inhibition) against the NCI60/ATCC panel of human cancer cell lines of different tissue origin; A549 (lung), MIA PaCa-2 (pancreatic), HCT-116 (colon), T47D (breast), PC3 (prostate), OVCAR-3 (ovarian). This study highlighted the crude ethyl acetate extract of $P$. pinophilum as a persuasive resource of natural cytotoxic agents. 2D SEPBOX fractionation/purification of the cytotoxically active ethyl acetate extract yielded a series of anthraquinones including monomeric/dimeric trihydroxyanthraquinones, i.e., oxyskyrin, skyrin, dicatenarin, and 1,6,8-trihydroxy-3-hydroxymethylanthraquinone. This is the first report from the $P$. pinophilum species producing these anthraquinones. Earlier reports have shown that $P$. pinophilum has produced a secondary metabolite, 3-0-methylfunicone, which showed apoptotic potential on human breast cancer (MCF-7) cells [18]. In vitro cytotoxic (\% growth inhibition) evaluation data against the NCI60/ATCC panel of human cancer cell lines of different tissue origin revealed that among all of the isolated compounds, dicatenarin and skyrin demonstrated promising cytotoxic potential with the lowest IC $\mathrm{I}_{50}$ values of $12 \mu \mathrm{g} / \mathrm{mL}$ and $27 \mu \mathrm{g} / \mathrm{mL}$, respectively, against human pancreatic cancer (MIA PaCa-2) cells. Skyrin was reported earlier as a glucagon antagonist and isolated previously from both lichens Lasallia and Trypetheliopsis boninensis and fungi including P. islandicum, Penicillium rugulosum, and Penicillium funiculosum [19]. Skyrin has also been isolated from the genus Talaromyces (Penicillium) and the species Wortmannii, which has also produced other steroid metabolites, i.e., wortmannin, which is a specific inhibitor of phosphoinositide 3-kinases and related enzymes such as mTOR, DNA-PK, and mitogen-activated protein kinase at high concentrations. 1,6,8-Trihydroxy-3-hydroxymethylanthraquinone has been reported for antibacterial, i.e., leishmanicidal, activity [13]. Dicatenarin has never been explored for any pharmacological activities. We are reporting, for first time, its significant cytotoxic potential against human pancreatic cancer. To examine whether dicatenarin and skyrin were merely killing the cells through cytotoxic action or

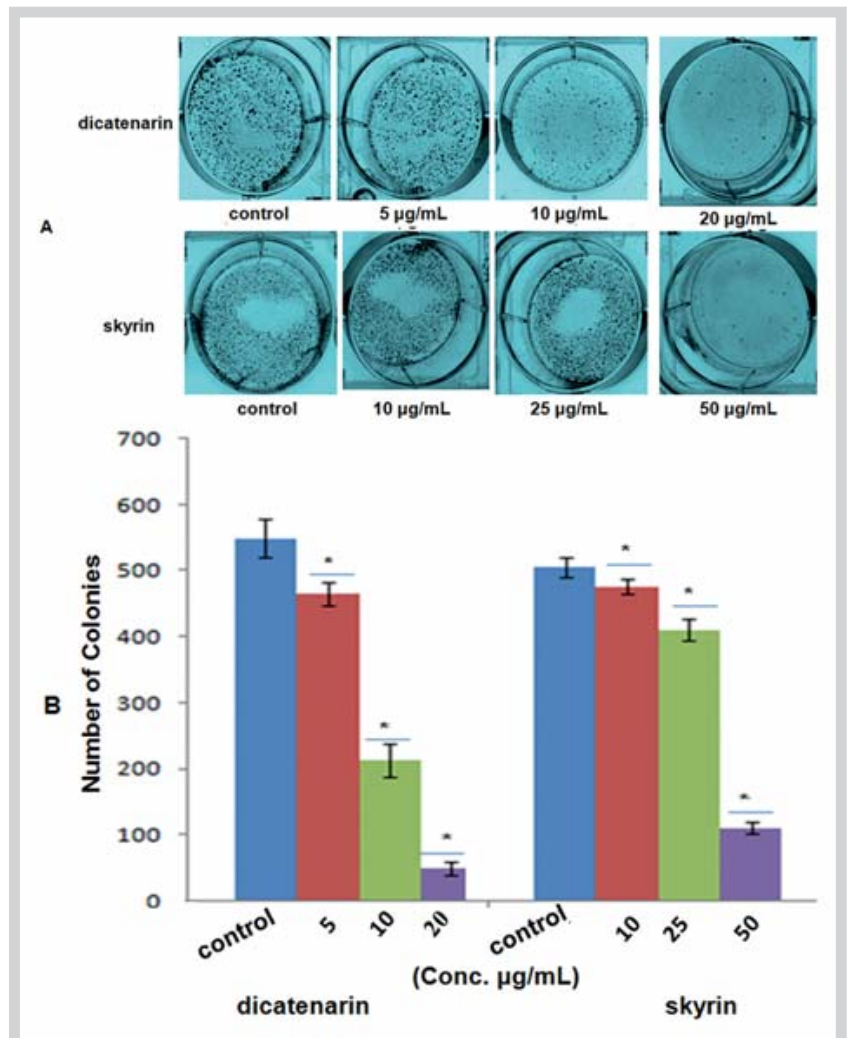

Fig. 10 Clonogenic ability was assessed in MIA PaCa-2 cells after dicatenarin and skyrin treatment. The representative images are shown. A Reduction in colony forming capability was determined in MIA PaCa- 2 cells. Cells $\left(1 \times 10^{3} / \mathrm{mL} /\right.$ well) were seeded in 6 -well plates and treated with different concentrations of dicatenarin $(5,10,20 \mu \mathrm{g} / \mathrm{mL})$ and skyrin $(10,25$, $50 \mu \mathrm{g} / \mathrm{mL}$ ). The number of crystal violet stained colonies were counted randomly after 7 days, quantified, and photographed. B Data are presented as mean \pm SD and statistical analysis was done with ${ }^{*} p<0.05$. (Color figure available online only.)

by inducing apoptosis, we analyzed the human pancreatic cancer (MIA PaCa-2) cells for change in preliminary morphological characteristics typical for apoptosis upon treatment with test materials by staining the nuclei with DAPI. Dicatenarin induced pronounced chromatin condensation and fragmentation of the nuclei of the cells in a concentration-dependent manner, whereas the effect was not pronounced much in skyrin-treated cells. Annexin V/PI dual staining suggested that in the event of early cell death, phosphatidylserine externalization was more significant in dicatenarin-treated cells compared to skyrin. To gain insight into the mechanism by which dicatenarin and skyrin results in cell death, we next examined ROS production, since the excessive generation of ROS results in cell injury and death [20]. Both dicatenarin and skyrin increased ROS/oxidative stress in MIA PaCa-2 cells in a concentration-dependent manner, but the phenomenon was much higher in the case of dicatenarin. Mitochondria play an important role in energy production and are also important sensors for apoptosis. Mitochondria-mediated ROS generation is a major source of oxidative stress in the cell [20]. We measured changes in MTP with a laser scanning confocal microscope, which revealed a considerable loss of MTP in human pancreatic cancer (MIA PaCa-2) cells treated with different concentrations of both dicatenarin and skyrin. Mitochondria manages apoptotic signals that not only include the generation of ROS and loss of MTP, but 
also the release of cytochrome c, which recruits effector caspases leading to programmed cell death. For further analysis of the apoptotic pathway, the release of cytochrome $c$ and the induction of caspase(s) was studied. Our immunofluorescence data revealed colocalization between mitochondria and cytochrome c. Cytochrome $\mathrm{c}$ was found to be highly colocalized with mitochondria in the untreated control cells. In contrast, MIA PaCa-2 cells exposed to dicatenarin and doxorubicin (positive control) treatment exhibited diffused cytoplasmic distribution of cytochrome c from the transition pores of the mitochondria into the cytosol, whereas skyrin-treated human pancreatic cancer (MIA PaCa-2) cells showed mild cytochrome $c$ release at a higher concentration. Since it is a key event in initiating the caspase cascade involving caspase-3, we confirmed the participation of activated caspase- 3 in the events of apoptosis induced by dicatenarin and skyrin. Caspase-3 acivity was significantly elevated in dicatenarin-treated human pancreatic cancer cells (MIA PaCa-2). Comparatively, there is the least increament in caspase-3 activity in skyrin-treated MIA PaCa- 2 cells after $48 \mathrm{~h}$ treatment. To assess the effect of the test material(s) on proliferation, growth, survival, and colongenic ability, human pancreatic cancer (MIA PaCa-2) cells were treated with different concentrations of test material (s) for colony formation. Both of the compounds produced a concentration-dependent inhibitory effect on the ability of the cells to reproduce and form large colonies. The untreated control showed overlapping colonies, whereas no overlapping was observed in both of the compounds. Considering the true pharmacological potential of isolated and well-characterized secondary metabolites, i.e., dicatenarin (3) and skyrin (2) of $P$. pinophilum isolated from the bulb of snow mountain garlic (Allium sp.), further studies are required to mechanistically evaluate and optimize the identified leads for cancer.

In conclusion, we have isolated and characterized four compounds (1-4) from the endophytic fungus P. pinophilum (MRCJ326 ) associated with the bulbs of $A$. schoenoprasum. All of the isolated compounds were tested against a panel of human cancer cell lines. As shown in $\odot$ Table 1, two compounds, dicatenarin (3) and skyrin (2), exhibited marked cytotoxic and proapoptotic potential, while compounds $\mathbf{1}$ and $\mathbf{4}$ were found inactive against the tested cell lines. Our results indicate that dicatenarin induced apoptosis through an apoptotic signal via intracellular ROS generation, and thereby a loss of MTP, and the induction of the mitochondrial-mediated apoptotic pathway. Cytochrome c release from the mitochondrial transition pore further resulted in an increased expression of apoptotic effector protein caspase- 3 for the execution of programmed cell death. In compounds 1 and $\mathbf{4}$, the methyl group at the $\mathrm{C}-3$ position was oxidized to primary alcohol and converted into $\mathrm{CH}_{2} \mathrm{OH}$, which leads to the complete loss of its activity. These results also suggested that in 1,6,8-trihydroxy anthraquinone, the $\mathrm{C}-3$ methyl group played a significant role in the cytotoxic potential as in skyrin and dicatenarin. Based on the bioactivity potential of these compounds, they can be studied further mechanistically and optimized for development as anticancer leads.

\section{Materials and Methods}

$\nabla$

\section{Chemicals and Reagents}

Cetyltrimethylammonium bromide, deuterated solvents, and $\mathrm{CD}_{3} \mathrm{OD}$ used in this study were obtained from Sigma-Aldrich. ${ }^{1} \mathrm{H},{ }^{13} \mathrm{C}$, and 2D-NMR spectra were recorded on $400 \mathrm{MHz}$ instru- ments (Bruker). The chemical data for the protons was reported in parts per million (p.p.m.) downfield from tetramethylsilane and are referenced to the residual proton in the NMR solvent $\left(\mathrm{CD}_{3} \mathrm{OD}: 3.31 \mathrm{ppm}\right)$. ESIMS were recorded on an Agilent 1100 LC-QTOF mass spectrometer. HPLC grade solvents like ACN and $\mathrm{MeOH}$ used for 2D-HPLC were purchased from SD Fine Chemical Limited. Water used for extractions was obtained from a Milli-Q Advantage A10 high-purity water system (Millipore). PDA, 1\% sodium hypochlorite, lactophenol-cotton-blue, 15\% glycerol, were purchased from Difco. The DNA purification kit was purchased from Qiagen. The caspase activity kit was purchased from Cell Signaling Technology. Dulbecco's modified Eagle's medium, Rosewell Park Memorial Institute medium (RPMI-1640), fetal bovine serum (10\%), rhodamine 123 (Rh 123), DAPI (Dilactate), DMSO, gentamycin sulphate, trypsin, EDTA, PBS penicillin, streptomycin, paclitaxel (purity $>95 \%$ by HPLC), mitomycin (purity $>95 \%$ by HPLC), doxorubicin (purity > 98\% by HPLC), gemcitabine (purity $>98 \%$ by HPLC), staurosporine (purity $>95 \%$ by HPLC), and all other chemicals were purchased from Sigma-Aldrich. Tris buffer was procured from Himedia. Glacial acetic acid was purchased from Fisher Scientific and trichloroacetic acid was from Merck Specialties Private Ltd.

Cell lines, cell culture, growth conditions, and treatment The human lung cancer cell line (A549), human colon cancer cell line (HCT-116), human breast cancer cell line (T47D), human prostate cancer cell line (PC3), and human ovarian cancer cell line (OVCAR-3) were obtained from the National Cancer Institute (NCI). The human pancreatic cancer cell line (MIA PaCa-2) was obtained from American Type Culture Collection (ATCC). The human pancreatic cancer cell line (MIA PaCa-2) and human colon cancer cell line (HCT-116) were maintained in Dulbecco's modified Eagle's medium. The human lung cancer cell line (A549), human breast cancer cell line (T47D), human prostate cancer cell line (PC3), and human ovarian cancer cell line (OVCAR-3) were maintained in RPMI. The media was supplemented with fetal bovine serum $(10 \%)$, penicillin (100 units/mL), streptomycin $(100 \mu \mathrm{g} / \mathrm{mL})$, and glutamine $\left(2 \mathrm{mM}\right.$ ). Cells were grown in $\mathrm{CO}_{2}$ (Thermo Scientific incubator) at $37^{\circ} \mathrm{C}$ with $98 \%$ humidity and $5 \% \mathrm{CO}_{2}$. The concentration of DMSO added to the test materials was maintained at $<0.2 \%$.

\section{Isolation and identification of endophytic fungi}

Plant samples, i.e., bulbs of $A$. schoenoprasum, were collected from the Western Himalayas from the snow mountain regions of Nattha top, J\&K, India. Samples were tagged, transported to the laboratory in sterile plastic bags, and stored at $4{ }^{\circ} \mathrm{C}$ until processed for isolation of the endophytic fungi. Samples were identified taxonomically by Dr. Sumeet Gairola, the Herbarium and Plant Sytematics Section, Plant Biotechnology Division, CSIR-IIIM, and given Crude Drug Repository Accession Number (CDR) 4029. Isolation of the endophytic fungi was carried out based on the procedures described earlier by Erza et al. [21]. The bulb samples were washed thoroughly with tap water to remove soil particles, sectioned into small pieces of $2-3 \mathrm{~cm}$, and surface sterilized with $1 \%$ sodium hypochlorite, followed by a rinse with sterile distilled water to remove traces of sodium hypochlorite and $90 \%$ ethanol. The outer tissues of the bulb samples were removed under sterile laminar air flow. Small sections of 0.5 to $1 \mathrm{~cm}$ were plated on the culture media, such as PDA and water agar, after passing through a flame. The plates were incubated at $25^{\circ} \mathrm{C}$ for 3 weeks. Hyphal tips of fungi, emerging out of the plant bulb samples, were picked and grown on a PDA plate until pure cultures were obtained. The 
cultures were stored in $15 \%$ glycerol and stored at $-70^{\circ} \mathrm{C}$. The isolated cultures were also submitted to the IIIM repository (IIIM Microbial repository No. MRCJ-326) for lyophilization and preservation.

Identification and characterization of the MRCJ-326 isolate was carried out by using morphological and molecular procedures. The morphological examination was performed by observing the microscopic characteristics of the fungal culture on PDA. Microscopic slides were prepared by staining with lactophenol cotton blue [22] and were examined under a light microscope (Olympus). Total genomic DNA of the fungal isolate was extracted according to Ausubel et al. [23] using CTAB (cetyltrimethylammonium bromide) as per the manufacturer's protocol. Fungal identification methods were based on their ITS of the fungal ribosomal DNA (ITS1-5.8 S-ITS2), and were amplified using universal primers ITS4 (5'TCCTCCGCTTATTGATATGC3') and ITS5 (5'GGAAGTAAAAGTCGTAACAA3'). The thermal cycling program used was as follows: $3 \mathrm{~min}$ initial denaturation at $94^{\circ} \mathrm{C}$, followed by 30 cycles of $15 \mathrm{sec}$ denaturation at $94^{\circ} \mathrm{C}, 30 \mathrm{sec}$ primer annealing at $55^{\circ} \mathrm{C}, 45 \mathrm{sec}$ extension at $72^{\circ} \mathrm{C}$, and a final 7-min extension at $72^{\circ} \mathrm{C}$. The PCR amplified products were visualized on $1 \%(\mathrm{w} / \mathrm{v})$ agarose gel. The amplicons were purified by using a DNA purification kit (Qiagen) and the purified product was used for sequencing the DNA. The corresponding ITS-rDNA sequence of the endophytic fungus was then used for similarity analysis using a BlastN algorithm against the public database at the National Center for Biotechnology Information (NCBI; http://www.ncbi.nlm. nih.gov).

\section{Extraction and isolation of fungal metabolites}

The endophytic fungal isolate P. pinophilum (MRCJ-326) was cultured in $25 \mathrm{~L}$ of potato dextrose broth for 10 days at $25^{\circ} \mathrm{C}$ and 180 $\mathrm{rev} / \mathrm{min}$. The fermentation culture was then filtered using muslin cloth. The filtrate was extracted with ethyl acetate $(10 \mathrm{~L}, 16 \mathrm{~h}$ ) successively five times. The extract was evaporated separately to dryness using rotavapor at $30^{\circ} \mathrm{C}$.

LC-MS is the preferred technique for the separation and detection of the large and often unique group of semi-polar secondary metabolites in natural product extracts. Specifically, LC-MS enables the detection of large numbers of parent ions present in a single extract and provides valuable information on the chemical composition and thus the putative identity of large numbers of metabolites. In our study, the ethyl acetate extract was analyzed using LC-MS (Agilent), a reversed-phase C18 (RP-C18) HPLC equipped with a photodiode array detector and triple quadrupole MS. The first $0-15$ min of the run was a gradient from $10-50 \%$ aqueous ( $0.1 \%$ formic acid) ACN to $75 \%$ ACN in the next $10 \mathrm{~min}$, followed by a $75 \%$ aqueous ( $0.1 \%$ formic acid) ACN wash for $5 \mathrm{~min}$ to complete a total run of $30 \mathrm{~min}$. A flow rate of $0.45 \mathrm{~mL} / \mathrm{min}$ was employed. The column utilized during this experiment was a Merck Chromolith RP 18e, $50 \times 4.6 \mathrm{~mm}, 5 \mu \mathrm{m}$ pore size ( $\mathrm{Fig} .3$ ).

\section{D-SEPBOX purification/fractionation of extract}

SEPBOX is based on a combination of HPLC and solid-phase extraction. One of its types, 2D-SEPBOX, can detect almost all substances by using two detection systems [ultraviolet (UV) detection and an optional evaporative light scattering detection, ELSD]. This purification was performed for the ethyl acetate extract. The extract (150 mg) was dissolved in methanol $(15 \mathrm{~mL})$, membrane filtered, and then mixed with sorbent C4 silica (10 g, sepiatec, 360-200 mesh). The mixture was dried under vacuum to remove the residual solvent, thus yielding a free-flowing powder. The sample was then loaded onto a stainless steel column $(8 \mathrm{~mm}$ $\mathrm{D} \times 60 \mathrm{~mm} \mathrm{~L}$ ), leaving one side open and $1 \mathrm{~g}$ of blank $\mathrm{C} 4$ silica material ( $1.0 \mathrm{~g})$ was added. After levelling the surface of the stationary phase, the adsorbed extract was funnelled onto the top of the stationary phase, the surface was levelled, the remaining volume of the injection column was filled with blank C4 silica material, the column end fitting was attached, and then the injection column was connected to the SEPBOX 2D-250-HPLC system (Sepiatec). Using HPLC grade water as solvent A and methanol as solvent $B$, the effluent of the injection column was continuously pumped onto a $150 \times 16 \mathrm{~mm}$, i.d., $5 \mu \mathrm{m}$, VP150/16 Nucleoprep 100-12 C4 end-capped column at a flow rate of $4.5 \mathrm{~mL} / \mathrm{min}$. Chromatography was performed with the following gradient: $0 \mathrm{~min}, 20 \% \mathrm{~B} ; 10 \mathrm{~min}, 50 \% \mathrm{~B} ; 20 \mathrm{~min}, 100 \% \mathrm{~B} ; 30 \mathrm{~min}, 100 \% \mathrm{~B}$; $31 \mathrm{~min}, 20 \% \mathrm{~B} ; 37 \mathrm{~min}, 20 \% \mathrm{~B}$. Concomitant with the separation, a flow gradient was run with water, which was mixed with the $C 4$ column effluent using the following flow rates: $0 \mathrm{~min}, 0 \mathrm{~mL} / \mathrm{min}$; $1 \mathrm{~min}, 50 \mathrm{~mL} / \mathrm{min} ; 12 \mathrm{~min}, 25 \mathrm{~mL} / \mathrm{min} ; 16 \mathrm{~min}, 20 \mathrm{~mL} / \mathrm{min}$; $21 \mathrm{~min}, 20 \mathrm{~mL} / \mathrm{min} ; 24 \mathrm{~min}, 1 \mathrm{~mL} / \mathrm{min}$. The effluent was collected in 16 subfractions, namely EA/1-EA/16, which were trapped onto VP30/32 Nucleoprep 100-12 C4 end-capped solid-phase extraction columns preconditioned with water ( $10 \mathrm{~min}, 8 \mathrm{~mL} / \mathrm{min}$ ) prior to the separation. Each subfraction was further separated on a $250 \times 10 \mathrm{~mm}, 5 \mu \mathrm{m}$, Luna Phenyl-Hexyl column (Phenomenex) using the following gradient of water (solvent A), methanol (solvent $B$ ), and $A C N$ (solvent $C$ ) at a flow rate of $4.5 \mathrm{~mL} / \mathrm{min}$ : fraction $\mathrm{EA} / 1,0 \mathrm{~min}, \mathrm{~A} / \mathrm{B} / \mathrm{C}(100: 0: 0), 60 \mathrm{~min}, \mathrm{~A} / \mathrm{B} / \mathrm{C}(100: 0: 0), 65 \mathrm{~min}$, $A / B / C$ (90:0:10), $72 \mathrm{~min}, A / B / C(0: 50: 50)$; fraction $E A / 2,0$ min, $38 \% \mathrm{~B}, 29 \mathrm{~min}, 58 \% \mathrm{~B}, 30 \mathrm{~min}, 100 \% \mathrm{~B}, 34 \mathrm{~min}, 100 \% \mathrm{~B}$; fraction EA/3, 0 min, A/B/C (56:44:0), $29 \mathrm{~min}, A / B / C ~(37: 63: 0), 30 \mathrm{~min}$, $A / B / C(0: 100: 0), 34 \mathrm{~min}, A / B / C(0: 100: 0)$; fraction $E A / 4,0$ min, $\mathrm{A} / \mathrm{B} / \mathrm{C} \quad(48: 52: 0), 29 \mathrm{~min}, \mathrm{~A} / \mathrm{B} / \mathrm{C}(23: 67: 0), 30 \mathrm{~min}, \mathrm{~A} / \mathrm{B} / \mathrm{C}$ $(0: 100: 0), 34 \mathrm{~min}, \mathrm{~A} / \mathrm{B} / \mathrm{C}(0: 100: 0)$; fraction $\mathrm{EA} / 5,0 \mathrm{~min}, \mathrm{~A} / \mathrm{B} / \mathrm{C}$ (32:68:0), $29 \mathrm{~min}, \mathrm{~A} / \mathrm{B} / \mathrm{C}(28: 72: 0), 30 \mathrm{~min}, \mathrm{~A} / \mathrm{B} / \mathrm{C}(0: 100: 0)$, $34 \mathrm{~min}, \mathrm{~A} / \mathrm{B} / \mathrm{C}(0: 100: 0)$; fraction $\mathrm{EA} / 6,0 \mathrm{~min}, \mathrm{~A} / \mathrm{B} / \mathrm{C}(31: 69: 0)$, $29 \mathrm{~min}, \mathrm{~A} / \mathrm{B} / \mathrm{C}(20: 80: 0), 30 \mathrm{~min}, \mathrm{~A} / \mathrm{B} / \mathrm{C}(0: 100: 0), 34 \mathrm{~min}, \mathrm{~A} / \mathrm{B} / \mathrm{C}$ $(0: 100: 0)$; fraction $\mathrm{EA} / 7,0 \mathrm{~min}, \mathrm{~A} / \mathrm{B} / \mathrm{C}(22: 78: 0), 29 \mathrm{~min}, \mathrm{~A} / \mathrm{B} / \mathrm{C}$ (13:87:0), $30 \mathrm{~min}, \mathrm{~A} / \mathrm{B} / \mathrm{C}(0: 100: 0), 34 \mathrm{~min}, \mathrm{~A} / \mathrm{B} / \mathrm{C}(0: 100: 0)$; fraction $\mathrm{EA} / 8,0 \mathrm{~min}, \mathrm{~A} / \mathrm{B} / \mathrm{C}(22: 78: 0), 29 \mathrm{~min}, \mathrm{~A} / \mathrm{B} / \mathrm{C}(9: 91: 0)$, $30 \mathrm{~min}, \mathrm{~A} / \mathrm{B} / \mathrm{C}(0: 100: 0), 34 \mathrm{~min}, \mathrm{~A} / \mathrm{B} / \mathrm{C}(0: 100: 0)$; fraction $\mathrm{EA} /$ 9, $0 \mathrm{~min}, A / B / C$ (21:79:0), $29 \mathrm{~min}, A / B / C$ (9:91:0), $30 \mathrm{~min}, A / B /$ $C(0: 100: 0), 34 \mathrm{~min}, A / B / C(0: 100: 0)$; fraction $E A / 10,0 \mathrm{~min}, A /$ $\mathrm{B} / \mathrm{C}(22: 88: 0), 29 \mathrm{~min}, \mathrm{~A} / \mathrm{B} / \mathrm{C}(7: 93: 0), 30 \mathrm{~min}, \mathrm{~A} / \mathrm{B} / \mathrm{C}(0: 100: 0)$, $34 \mathrm{~min}, \mathrm{~A} / \mathrm{B} / \mathrm{C}(0: 100: 0)$; fraction $\mathrm{EA} / 11,0 \mathrm{~min}, \mathrm{~A} / \mathrm{B} / \mathrm{C}(7: 93: 0)$, $29 \mathrm{~min}, \mathrm{~A} / \mathrm{B} / \mathrm{C}(5: 95: 0), 30 \mathrm{~min}, \mathrm{~A} / \mathrm{B} / \mathrm{C}(0: 100: 0), 34 \mathrm{~min}, \mathrm{~A} / \mathrm{B} / \mathrm{C}$ $(0: 100: 0)$; fraction $\mathrm{EA} / 12,0 \mathrm{~min}, \mathrm{~A} / \mathrm{B} / \mathrm{C}(3: 97: 0), 16 \mathrm{~min}, \mathrm{~A} / \mathrm{B} / \mathrm{C}$ (3:97:0), $17 \mathrm{~min}, A / B / C(0: 100: 0), 29 \mathrm{~min}, A / B / C(0: 93: 7)$, $30 \mathrm{~min}, \mathrm{~A} / \mathrm{B} / \mathrm{C}(0: 50: 50), 34 \mathrm{~min}, \mathrm{~A} / \mathrm{B} / \mathrm{C}(0: 50: 50)$; fraction $\mathrm{EA} /$ $13,0 \mathrm{~min}, \mathrm{~A} / \mathrm{B} / \mathrm{C}(3: 97: 0), 16 \mathrm{~min}, \mathrm{~A} / \mathrm{B} / \mathrm{C}(3: 97: 0), 17 \mathrm{~min}, \mathrm{~A} / \mathrm{B} /$ $C(0: 100: 0), 29 \mathrm{~min}, A / B / C(0: 93: 7), 30 \mathrm{~min}, A / B / C(50: 50: 0)$, $34 \mathrm{~min}, \mathrm{~A} / \mathrm{B} / \mathrm{C}(0: 50: 50)$; fraction $\mathrm{EA} / 14,0 \mathrm{~min}, \mathrm{~A} / \mathrm{B} / \mathrm{C}(0: 98: 2)$, $29 \mathrm{~min}, \mathrm{~A} / \mathrm{B} / \mathrm{C}(0: 89: 11), 30 \mathrm{~min}, \mathrm{~A} / \mathrm{B} / \mathrm{C}(0: 50: 50), 34 \mathrm{~min}, \mathrm{~A} / \mathrm{B} / \mathrm{C}$ $(0: 50: 50)$; fraction $\mathrm{EA} / 15,0 \mathrm{~min}, \mathrm{~A} / \mathrm{B} / \mathrm{C}(0: 98: 2), 29 \mathrm{~min}, \mathrm{~A} / \mathrm{B} / \mathrm{C}$ (0:80:20), $30 \mathrm{~min}, \mathrm{~A} / \mathrm{B} / \mathrm{C}(0: 50: 50), 34 \mathrm{~min}, \mathrm{~A} / \mathrm{B} / \mathrm{C}(0: 50: 50)$; fraction $\mathrm{EA} / 16, \quad 0 \mathrm{~min}, \mathrm{~A} / \mathrm{B} / \mathrm{C} \quad(0: 100: 0), 29 \mathrm{~min}, \mathrm{~A} / \mathrm{B} / \mathrm{C}$ $(0: 34: 66), 30 \mathrm{~min}, \mathrm{~A} / \mathrm{B} / \mathrm{C}(0: 10: 90), 34 \mathrm{~min}, \mathrm{~A} / \mathrm{B} / \mathrm{C}(0: 10: 90)$. Column equilibration for each separation was $10 \mathrm{~min}$ at the initial gradient conditions. Each subfraction, EA/1-16, was separated/ collected into subfractions in 48 -well plates ( $4 \mathrm{~mL} /$ well) based on its purity. Well numbers $7,8,11$, and 44 contained the compounds dicatenarin (3), oxyskyrin (1), skyrin (2), and 1,6,8-trihydroxy-3-hydroxymethylanthraquinone (4) sequentially. Com- 
pounds from these wells were first collected and dried under vacuum for further NMR and MS spectroscopic analysis.

Oxyskyrin (1): Orange-red amorphous solid; m.p. $>361^{\circ} \mathrm{C}$; UV $\lambda_{\max } / \mathrm{nm}(\mathrm{MeOH}): 215,256,300$, and $462 ;{ }^{1} \mathrm{H}$ NMR $(400 \mathrm{MHz}$, methanol- $\left.d_{4}\right): \delta_{\mathrm{H}} 2.48\left(3 \mathrm{H}\right.$, brs, $\left.\mathrm{CH}_{3}-11^{\prime}\right), \delta_{\mathrm{H}} 4.87\left(2 \mathrm{H}, \mathrm{s}, \mathrm{CH}_{2}-\right.$ $11), \delta_{\mathrm{H}} 7.26(1 \mathrm{H}, \mathrm{brs}, \mathrm{H}-2), \delta_{\mathrm{H}} 7.09\left(1 \mathrm{H}, \mathrm{brs}, \mathrm{H}-2^{\prime}\right), \delta_{\mathrm{H}} 6.81(2 \mathrm{H}$, s, H-7,7'), $\delta_{\mathrm{H}} 7.66(1 \mathrm{H}, \mathrm{d}, J=2.6 \mathrm{~Hz}, \mathrm{H}-4), 7.51(1 \mathrm{H}, \mathrm{d}, J=2.6 \mathrm{~Hz}$, H-4'), ESIMS: $m / z$ 554.9, LC-HRMS (full scan) calcd. for $\mathrm{C}_{30} \mathrm{H}_{17} \mathrm{O}_{11}[\mathrm{M}-\mathrm{H}]^{-} \mathrm{m} / z 553.2(100 \%)[11,12]$.

Skyrin (2): Orange red powder; m.p. $>300^{\circ} \mathrm{C}$; UV $\lambda_{\max } / \mathrm{nm}$ (MeOH): 212, 256, 302, and 459; ${ }^{1} \mathrm{H}$ NMR ( $400 \mathrm{MHz}$, methanol$\left.d_{4}\right): \delta_{\mathrm{H}} 2.35\left(6 \mathrm{H}\right.$, brs, $\left.\mathrm{CH}_{3}-11,11^{\prime}\right), \delta_{\mathrm{H}} 7.21\left(2 \mathrm{H}, \mathrm{brs}, \mathrm{H}-2,2^{\prime}\right), \delta_{\mathrm{H}}$ $6.63\left(2 \mathrm{H}\right.$, ssss, H-7,7'), $\delta_{\mathrm{H}} 7.50$ (2 H, brs, H-4,4'); LC-HRMS (full scan) calcd. for $\mathrm{C}_{30} \mathrm{H}_{17} \mathrm{O}_{10}[\mathrm{M}-\mathrm{H}]^{-} \mathrm{m} / z 537.2$ (100\%) [11,12].

Dicatenarin (3): Orange amorphous powder, m.p. $>320^{\circ} \mathrm{C}$; UV $\lambda_{\max } / \mathrm{nm}(\mathrm{MeOH}): 212,265,307$, and $465 ;{ }^{1} \mathrm{H}$ NMR $(400 \mathrm{MHz}$, methanol- $\left.d_{4}\right): \delta_{\mathrm{H}} 2.21\left(6 \mathrm{H}\right.$, brs, $\left.\mathrm{CH}_{3}-11,11^{\prime}\right), \delta_{\mathrm{H}} 7.25$, (brs, $2 \mathrm{H}-$ $\left.2,2^{\prime}\right), \delta_{\mathrm{H}} 6.60$ (brs, $2 \mathrm{H}, \mathrm{H}-7,7^{\prime}$ ); LC-HRMS (full scan) calcd. for $\mathrm{C}_{30} \mathrm{H}_{17} \mathrm{O}_{12}[\mathrm{M}-\mathrm{H}]^{-} \mathrm{m} / z 569.2$ (100\%) [12].

1,6,8-trihydroxy-3-hydroxymethylanthraquinone (4): Yellow-orange needles; m.p. $285-290^{\circ} \mathrm{C}$; UV $\lambda_{\max } / \mathrm{nm}\left(\mathrm{CH}_{2} \mathrm{Cl}_{2}\right): 232,260$, 308, and $372{ }^{1} \mathrm{H}$ NMR (400 MHz, methanol- $\left.d_{4}\right): \delta_{\mathrm{H}} 4.76(2 \mathrm{H}, \mathrm{s}$, $\left.\mathrm{CH}_{2}-11\right), \delta_{\mathrm{H}} 6.75(1 \mathrm{H}, \mathrm{d}, J=2.1 \mathrm{~Hz}, \mathrm{H}-7), \delta_{\mathrm{H}} 7.20(1 \mathrm{H}, \mathrm{d}$, $J=2.1 \mathrm{~Hz}, \mathrm{H}-5), \delta_{\mathrm{H}} 7.25\left(1 \mathrm{H}\right.$, brs, H-2), $\delta_{\mathrm{H}} 7.69(1 \mathrm{H}$, brs, $\mathrm{H}-4)$; LC-HRMS (full scan) calcd. for $\mathrm{C}_{15} \mathrm{H}_{09} \mathrm{O}_{6}[\mathrm{M}-\mathrm{H}]^{-} \mathrm{m} / \mathrm{z} 285.3$ (100\%) [13].

\section{In vitro cytotoxicity sulphorhodamine B assay}

Potential cell cytotoxicity of the crude ethyl acetate extract and isolated compounds were evaluated against a panel of human cancer cell lines. Test materials (extract and isolated compounds) were dissolved in DMSO and serially diluted at different concentrations $(1,10,30,50,100 \mu \mathrm{g} / \mathrm{mL})$. Human cancer cell lines were seeded in 96-well plates at a cell density of $10^{4}$ cells/well for $24 \mathrm{~h}$ before treatment with the test material to allow the attachment of the cell to the plate. Serially diluted test materials were added to the cells in triplicate after being prepared for each individual concentration and were further incubated with the compound for $48 \mathrm{~h}$ at $37^{\circ} \mathrm{C}$ in atmosphere of $5 \% \mathrm{CO}_{2}$. After $48 \mathrm{~h}$, the cells were fixed with chilled $50 \%$ trichloroacetic acid, dried, and stained with sulphorhodamine B dye. The excess dye was washed with $1 \%$ glacial acetic acid and the remaining cell bound dye was dissolved in Tris EDTA buffer and colorimetrically measured at $540 \mathrm{~nm}$ in a Biotek ELISA reader [24,25].

\section{Nuclear morphology studies}

The presence of apoptotic cells were determined by staining MIA $\mathrm{PaCa}-2$ cells with DAPI. Human pancreatic cancer (MIA PaCa-2) cells $\left(2 \times 10^{5} / \mathrm{mL} /\right.$ well $)$ were seeded in $60 \mathrm{~mm}$ culture dishes. After $24 \mathrm{~h}$, the cells were incubated with different concentrations of dicatenarin $(5,10,20 \mu \mathrm{g} / \mathrm{mL})$, skyrin $(10,25,50 \mu \mathrm{g} / \mathrm{mL})$, and paclitaxel $(1 \mu \mathrm{g} / \mathrm{mL})$ for $48 \mathrm{~h}$. The media was collected and the cells were rinsed with PBS, detached by trypsinization, and added back to the conditioned media to ensure that floating and poorly attached cells were included in the analysis. Air-dried smears of MIA PaCa-2 cells were fixed in methanol at $-20^{\circ} \mathrm{C}$ for $20 \mathrm{~min}$, air-dried, and stained with DAPI at $1 \mu \mathrm{g} / \mathrm{mL}$ in PBS at room temperature for $20 \mathrm{~min}$ in the dark and the slides were mounted in glycerol-PBS $(1: 1)$ and examined with an inverted fluorescence microscope (Olympus, 1X81) [26].

\section{Detection of apoptosis by annexin V-fluorescein} isothiocyanate and propidium iodide

Annexin V-FITC and PI dual staining is usually used to detect the early and late apoptotic cells. For measuring apoptosis, human pancreatic cancer (MIA PaCa-2) cells were seeded in 6-well plates $\left(2 \times 10^{5}\right.$ cells $/ \mathrm{mL} /$ well $)$ and treated with dicatenarin $(20 \mu \mathrm{g} / \mathrm{mL})$ and skyrin $(50 \mu \mathrm{g} / \mathrm{mL})$ for $48 \mathrm{~h}$. Paclitaxel $(1 \mu \mathrm{g} / \mathrm{mL})$ was used as a positive control. After $48 \mathrm{~h}$ treatment, the cells were collected, washed twice with PBS, and resuspended in binding buffer. There after, the cells were stained with annexin V/FITC and PI for $15 \mathrm{~min}$ in the dark and analyzed by a laser scanning confocal microscope (Olympus Fluoview FV 1000) [27].

\section{Detection of intracellular reactive oxygen species accumulation}

Intracellular ROS levels were monitored by fluorescence microscopy after staining with DCFH-DA. Human pancreatic cancer (MIA PaCa-2) cells $\left(2 \times 10^{5} / \mathrm{mL} /\right.$ well $)$ were seeded in $60 \mathrm{~mm}$ culture dishes. After $24 \mathrm{~h}$, the cells were incubated with different concentrations of dicatenarin $(5,10,20 \mu \mathrm{g} / \mathrm{mL})$ and skyrin $(25$, $50 \mu \mathrm{g} / \mathrm{mL}$ ) for $48 \mathrm{~h} . \mathrm{H}_{2} \mathrm{O}_{2}(0.05 \%)$ was used as a positive control. Following treatment, the medium was removed and the cells were loaded with $5 \mu \mathrm{M}$ DCFH-DA diluted in incomplete medium for $30 \mathrm{~min}$ at $37^{\circ} \mathrm{C}$. The cells were washed three times with incomplete medium and were observed by a laser scanning confocal microscope at $10 \times[20]$.

\section{Loss of mitochondrial transmembrane potential}

Loss in MTP $(\Delta \psi \mathrm{m})$ as a result of mitochondrial perturbation was studied using confocal microscopy after staining with rhodamine 123 (Rh123). Human pancreatic cancer (MIA PaCa-2) cells $(2 \times$ $10^{5} / \mathrm{mL} /$ well) were seeded in 6 -well plates and treated with different concentrations of dicatenarin $(5,10,20 \mu \mathrm{g} / \mathrm{mL})$, skyrin $(10,25,50 \mu \mathrm{g} / \mathrm{mL})$, and paclitaxel $(1 \mu \mathrm{g} / \mathrm{mL})$ for $48 \mathrm{~h}$. The cells were trypsinized and washed twice with PBS. The cell pellets were then suspended in $2 \mathrm{ml}$ fresh medium containing Rh123 $(1.0 \mu \mathrm{M})$ and incubated at $37^{\circ} \mathrm{C}$ for $20 \mathrm{~min}$ with gentle shaking. The cells were collected by centrifugation and washed twice with PBS, then analyzed by a laser scanning confocal microscope (Olympus Fluoview FV1000) [28].

\section{Immunofluorescence confocal microscopy \\ for detection of cytochrome c}

The status of cytochrome c (intact or released) was examined by immunofluorescence microscopy. After $48 \mathrm{~h}$ treatment with dicatenarin $(5,10,20 \mu \mathrm{g} / \mathrm{mL})$, skyrin $(25,50 \mu \mathrm{g} / \mathrm{mL})$, paclitaxel $(1 \mu \mathrm{g} /$ $\mathrm{mL})$, and doxorubicin $(0.5 \mu \mathrm{g} / \mathrm{mL})$, human pancreatic cancer (MIA $\mathrm{PaCa}-2)$ cells $\left(2 \times 10^{5} / \mathrm{mL} /\right.$ well $)$ were processed for immunofluorescence microscopic studies for the detection of cytochrome $\mathrm{c}$ release. The cells were incubated with MitoTracker Red $(100 \mathrm{~nm})$ for $10 \mathrm{~min}$ in the dark. Then cells were fixed in $4 \%$ paraformaldehyde for $10 \mathrm{~min}$ at room temperature and permeabilized using $0.5 \%$ Triton-X in PBS for 5 min. The cells were blocked with $10 \%$ goat serum for $20 \mathrm{~min}$ at room temperature. The expression of cytochrome c proteins was detected by incubating the cells with specific primary antibody anti-cytochrome c (mouse) for $1 \mathrm{~h}$ at room temperature (dilution $1: 100$ ). The Alexa Fluor 488 conjugated secondary antibody was diluted 1:500 in PBS and incubated for $1 \mathrm{~h}$ at room temperature. The cells were then washed three times in PBS and stained with DAPI $(1 \mu \mathrm{g} / \mathrm{mL}$ in PBS). The coverslips were mounted over glass slides and the cells were im- 
aged by a laser scanning confocal microscope (Olympus, Fluoview FV 1000) at 40× with an oil immersion lens [29,30].

\section{Caspase- 3 activity}

Caspase-3 activity was determined using a commercial kit (Cell Signaling Technology) according to the manufacturer's instructions. Human pancreatic cancer (MIA PaCa-2) cells $\left(2 \times 10^{5} / \mathrm{mL} /\right.$ well) were seeded in 6-well plates and treated with dicatenarin $(5,10,20 \mu \mathrm{g} / \mathrm{mL})$, skyrin $(25,50 \mu \mathrm{g} / \mathrm{mL})$, and staurosporine $(0.5 \mu \mathrm{g} / \mathrm{mL})$ for $48 \mathrm{~h}$ following the same treatment as above. After treatment, the cells were harvested by centrifugation and the pellets were washed with PBS before lysis in chilled lysis buffer. The mixture was left on ice for $10 \mathrm{~min}$ and then centrifuged at $14000 \mathrm{~g}$ (Eppendorf Centrifuge, Sigma) at $4^{\circ} \mathrm{C}$ for $10 \mathrm{~min}$. The resulting supernatant was used for the determination of caspase activities. There results were read on a microplate reader at $405 \mathrm{~nm}[31]$.

\section{In vitro clonogenic assay}

A clonogenic assay was performed to determine the capability of a cell to grow into a colony. Human pancreatic cancer (MIA PaCa2 ) cells were plated at a seeding density of $1 \times 10^{3}$ cells $/ \mathrm{mL} /$ well in 6 -well plates. After $24 \mathrm{~h}$, the culture medium was changed and new medium was added, and the cells were exposed to different concentrations of dicatenarin $(5,10,20 \mu \mathrm{g} / \mathrm{mL})$ and skyrin $(10,25$, $50 \mu \mathrm{g} / \mathrm{mL}$ ) for 7 days in a $37^{\circ} \mathrm{C}$ incubator in $5 \% \mathrm{CO}_{2}$. Later on, the obtained colonies were fixed with $4 \%$ paraformaldehyde and were stained with $0.5 \%$ crystal violet solution $[32,33]$. The colonies from the plates were counted and photographed.

\section{Statistical analysis}

Results are expressed as mean \pm of SD of three individual experiments. Standard deviations were calculated using Graphpad prism and Microsoft excel. P values $<0.05$ were considered significant.

\section{Supporting information}

${ }^{13} \mathrm{C}-\mathrm{NMR}$ data of compounds $\mathbf{1 - 4}$ in $\mathrm{CD}_{3} \mathrm{OD}$, LC-MS dereplication data of the ethyl acetate extract, and key ${ }^{1} \mathrm{H}-{ }^{13} \mathrm{C}$ HMBC spectra of $\mathbf{1}$ and $\mathbf{2}$ are available as Supporting Information.

\section{Acknowledgements}

$\nabla$

We sincerely thank Dr. Sumeet Gairola, Scientist, Herbarium and Plant Sytematics Section Plant Biotechnology Division, CSIR-IIIM, Jammu, for identification of the plant material. We also thank DST, Government of India for financial support in the form of the DST-inspire award and fellowship to Mytre Koul and Ashok Kumar and UGC for RGNF to Samdarshi Meena.

\section{Conflict of Interest}

$\nabla$

The authors have no conflict of interest to declare.

\footnotetext{
Affiliations

${ }^{1}$ Cancer Pharmacology Division, CSIR-Indian Institute of Integrative Medicine, lammu, India

2 Natural Product Chemistry, CSIR-Indian Institute of Integrative Medicine, Jammu, India

3 Microbial Biotechnology Division, CSIR-Indian Institute of Integrative Medicine, Jammu, India

${ }^{4}$ Fermentation Technology Division, CSIR-Indian Institute of Integrative Medicine, Jammu, India

${ }^{5}$ Academy of Scientific \& Innovative Research (AcSIR), CSIR, New Delhi, India
}

\section{References}

1 Strobel GA. Endophytes as sources of bioactive products. Microbes Infect 2003; 5: 535-544

2 Nicoletti R, Buommino E, Tufano MA. Patenting Penicillium strains. Recent Pat Biotechnol 2012; 6: 81-96

3 Fleming $A$. The antibacterial action of cultures of a Penicillium, with special reference to their use in the isolation of $B$. influenzae. $\mathrm{Br} \mathrm{J}$ Exp Pathol 1929; 10: 226-236

4 Brown AG, Smale TC, King TJ, Hasenkamp R, Thompson RH. Crystal and molecular structure of compactin, a new antifungal metabolite from Penicillium brevicompactum. J Chem Soc Perkin 1976; 11: 65-70

$5 \mathrm{Yu}$ H, Zhang $L$, Li L. Recent developments and future prospects of antimicrobial metabolites produced by endophytes. Microbiol Res 2010; 165: 437-449

6 Kharwar RN, Mishra A, Gond SK, Stierle A, Stierle D. Anticancer compounds derived from fungal endophytes: their importance and future challenges. Nat Prod Rep 2011; 28: 1208-1228

7 Jayasuriya H, Koonchanok NM, Geahlen RL. Emodin, a protein tyrosine kinase inhibitor from Polygonum cuspidatum. J Nat Prod 1992; 55: 696-698

8 Nicoletti R, Ciavatta ML, Buommino E, Tufano MA. Antitumor extrolites produced by Penicillium species. Int J Biomed Pharma Sci 2008; 2: 1-23

9 Reuter HD. Allium sativum and Allium ursinum: Pharmacology and medical application. Phytomedicine 1995; 2: 73-91

10 Reuter HD, Koch HP, Lawson LD. Therapeutic effects and applications of garlic and its preparations. In: Koch HP, Lawson LD, editors. Garlic: the science and therapeutic application of Allium sativum L. and related species. Baltimore, MD: Williams and Wilkins; 1996: 135-213

11 Takeda N, Seo S, Ogihara Y, Sankawa U, Iitaka I, Kitagawa I, Shibata S. Studies on fungal metabolites-XXXI: Anthraquinonoid colouring matters of Penicillium islandicum sopp and some other fungi (-)luteoskyrin, (-)rubroskyrin, (+)rugulosin and their related compounds. Tetrahedron 1973; 29: 3703-3719

12 Bara R, Aly AH, Pretsch A, Wray V, Wang B, Proksch P, Debbab A. Antibiotically active metabolites from Talaromyces wortmanni an endophyte of Aloe vera. J Antibiot (Tokyo) 2013; 66: 491-493

13 Marinho AMR, Edson RF, Maria RM, Santos LS. Biologically active polyketides produced by Penicillium janthinellum isolated as an endophytic fungus from fruits of Melia azedarach. J Braz Chem Soc 2005; 16 : 280-283

14 Shah NC. Status of cultivated and wild Allium species in India: a review. Scitech J 2014; 1: 28-36

15 Riggs DR, DeHaven JI, Lamm DL. Allium sativum (garlic) treatment for murine transitional cell carcinoma. Cancer 1997; 79: 1987-1994

16 Garyali S, Kumar A, Reddy MS. Taxol production by an endophytic fungus, Fusarium redolens, isolated from Himalayan yew. J Microbiol Biotechnol 2013; 23: 1372-1380

17 Rukachaisirikul V, Kaeobamrung J, Panwiriyarat W, Saitai P, Sukpodma $Y$, Phongpaichit S, Sakayaroj J. A new pyrone derivative from the entophytic fungus Penicillium paxilli PSUA71. Chem Pharm Bull (Tokyo) 2007; 55: 1383-1384

18 Buommino E, Boccellino M, Filippis AD, Petrazzuolo M, Cozza V, Nicoletti $R$, Ciavatta ML, Quagliuolo L, Antonietta M. 3-O-Methylfunicone produced by Penicillium pinophilum affects cell motility of breast cancer cells, downregulating avb5 integrin and inhibiting metalloproteinase9 secretion. Mol Carcinog 2007; 46: 930-940

19 Parker JC, McPherson RK, Andrews KM, Levy CB, Dubins JS, Chin JE, Perry PV, Hulin B, Perry DA, Inagaki T, Dekker KA, Tachikawa K, Sugie Y, Treadway JL. Effects of skyrin, a receptor-selective glucagon antagonist, in rat and human hepatocytes. Diabetes 2000; 49: 2079-2086

20 Bai J, Lei Y, An G, He L. Down-regulation of deacetylase HDAC6 inhibits the melanoma cell line A375.S2 growth through ROS-dependent mitochondrial pathway. PLoS One 2015; 10: 1371-1382

21 Ezra D, Hess WM, Strobel GA. New endophytic isolates of Muscodor albus, a volatile-antibiotic-producing fungus. Microbiology 2004; 150 : 4023-4031

22 Vainio EJ, Korhonen K, Hantula J. Genetic variation in Phlebiopsis gigantean as detected with random amplified microsatellite (RAMS) markers. Mycol Res 1998; 2: 187-192

23 Ausubel FM, Brent R, Kingston RE, Moore DD, Seidman JG, Smith JA, Struhl $K$. Current protocols in molecular biology. New York City, NY: John Wiley \& Sons; 1994

24 Monks A, Scudeiro D, Skehan P, Shoemaker R, Paull K, Vistica D, Hose C, Langley J, Cronise P, Vaigro-Wolff A, Gray-Goodrich M, Campbell H, Mayo $J$, Boyd $M$. Feasibility of a high-flux anticancer drug screen using a di- 
verse panel of cultured human tumor cell lines. J Natl Cancer Inst 1991; 83: 757-766

25 Singh SK, Shanmugavel M, Kampasi H, Singh R, Mondhe DM, Rao JM, Adwankar MK, Saxena AK, Quazi GN. Chemically strandarized isolate from Cedrus deodara stem wood having anticancer activity. Planta Med 2007; 73: 519-526

26 Rello S, Stockert JC, Moreno V, Gamez A, Pacheco M, Juarranz A, Canete M, Villanueva A. Morphological criteria to distinguish cell death induced by apoptosis and necrotic treatments. Apoptosis 2005; 10: 201-208

27 Zhang H, Li H, Yang L, Deng Z, Luo H, Ye D, Bai Z, Zhu L, Ye W, Wang L, Chen $L$. The ClC-3 chloride channel associated with microtubules is a target of paclitaxel in its induced-apoptosis. Sci Rep 2013; 3: 2615

28 Dai J, Wang J, Li F, Ji Z, Ren T, Song Q. Scutellaria barbate extract induces apoptosis of hepatoma $\mathrm{H} 22$ cells via the mitochondrial pathway involving caspase-3. World J Gastroenterol 2008; 14: 7321-7328
29 Seervi M, Joseph J, Sobhan PK, Bhavya BC, Santhoshkuma TR. Essential requirement of cytochrome $c$ release for caspase activation by procaspase-activating compound defined by cellular models. Cell Death Dis 2011; 2: e207

30 Chen T, Pengetnze Y, Taylor C. Src inhibition enhances paclitaxel cytotoxicity in ovarian cancer cells by caspase-9-independent activation of caspase-3. Mol Cancer Ther 2005; 2: 217-224

31 Verma M, Singh SK, Bushan S, Pal HC, Kitchlu S, Koul MK, Thappa RK, Saxena $A K$. Induction of mitochondrial dependent apoptosis by an essential oil from Tanacetum gracile. Planta Med 2008; 74: 515-520

32 Munshi A, Hobbs M, Meyn RE. Clonogenic cell survival assay. Methods Mol Med 2005; 110: 21-28

33 Majeed R, Sangwan PL, Chinthakindi P, Khan I, Dangroo N, Thota N, Hamid A, Sharma PR, Saxena AK, Koul S. Synthesis of 3-O-propargylated betulinic acid and its 1,2,3-triazoles as potential apoptotic agents. Eur J Med Chem 2013; 63: 782-792 